\title{
Seed rain and establishment in successional forests in Chiapas, Mexico
}

\section{Lluvia de semillas y establecimiento en comunidades sucesionales en Chiapas, México}

\section{Acta Botanica Mexicana}

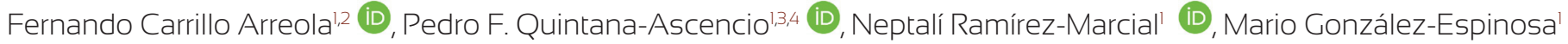

\begin{abstract}
:
Background and Aims: Agriculture in the tropics is decreasing, fragmenting and altering forests and forest landscapes. We hypothesized differences in species richness and dominance of life forms in the seed rain and in richness and survival in the recruit assemblages among mature forests, mid-successional forests, early successional forests, pastures and milpa fields (arable lands with maize) surrounded by natural and human disturbed habitats.

Methods: Samples of seeds and plants were collected during a year in Lacanjá-Chansayab and Bonampak-Bethel, in the buffer zone of the Montes Azules Biosphere Reserve, Selva Lacandona, Chiapas, Mexico. We deployed 14 seed traps in 12 sites representing a gradient of vegetation succession $(2$ sites $\times 6$ habitats $\times 14$ traps; $n=168$ traps). Independently, to assess changes in recruitment and early survival, we established 15 quadrats $(0.5 \times 2.0 \mathrm{~m})$ in each of the studied forests ( 2 sites $\times 3$ habitats $\times 15$ quadrats; $n=90$ quadrats).

Key results: We collected $\sim 13,600$ seeds of 144 species from 48 botanical families. Mature forests had the highest seed rain species richness (60-61) and pastures (14-11) the lowest. We observed a decline in species richness and a change in dominance of life forms in the seed rain from less disturbed to most perturbed habitats. Mature forests included seeds of diverse tree species while the assemblage in pastures was dominated by seeds of few grass species. Intensive traditional milpa fields showed homogeneous seed assemblages. For the new recruits, we recorded 3,416 individuals ( $<0.5 \mathrm{~m}$ height) of $238 \mathrm{morphospecies}$ in 42 families, 129 were identified to species level. The largest number of species occurred in mature and mid-successional stands compared to early forests. Annual survival of recruits was higher in mid- and late successional forests than in early ones.

Conclusions: We document species loss and widespread simplification and homogenization in community composition due to pervasive effect of humans on remnant tropical lowland forests.
\end{abstract}

Key words: forest landscapes, habitat heterogeneity, human disturbance, Lacandon Maya, swidden agriculture, tropical rainforest.

\section{Resumen:}

Antecedentes y Objetivos: La agricultura en los trópicos reduce, fragmenta y altera los bosques y los paisajes forestales. Evaluamos la riqueza de especies y la dominancia de formas de vida en la lluvia de semillas, y la abundancia y supervivencia anual de nuevos reclutas en bosques maduros, medianamente maduros, bosques tempranos, potreros y campos de cultivo en ambientes naturales y humanizados. Pronosticamos diferencias en composición y número de semillas y de reclutas en función de los diferentes hábitats y de las matrices de vegetación que los circundan.

Métodos: Durante un año se colectaron muestras de semillas y plantas en Lacanjá-Chansayab y Bonampak-Bethel, ambas dentro de la zona de amortiguamiento de la Reserva de la Biosfera de Montes Azules, Selva Lacandona, Chiapas, México. Para la lluvia de semillas, instalamos 14 trampas en sitios que representan el gradiente de sucesión en la vegetación local ( 2 sitios $\times 6$ hábitats $\times 14$ trampas; $n=168)$. Independientemente, para evaluar los cambios en reclutamiento y supervivencia tempranas se establecieron 15 cuadros $(0.5 \times 2.0 \mathrm{~m})$ en cada comunidad arbolada $(2$ sitios $\times 3$ comunidades $\times 15$ cuadros; $n=90)$. Resultados clave: Colectamos 13,600 semillas de 144 especies pertenecientes a 48 familias botánicas. Los bosques maduros presentaron la mayor riqueza (60-61) y los potreros la menor (14-11). Observamos una reducción en la riqueza de especies y un cambio en la dominancia de las formas de vida a través del gradiente sucesional. Los bosques incluyeron principalmente semillas de árboles, mientras los potreros estuvieron dominados por unas pocas especies de gramíneas. La lluvia de semillas en las áreas agrícolas se caracterizó por un reducido número de especies generalistas. Para los reclutas de especies leñosas, se registraron 3416 individuos (<0.5 m de altura) de 238 morfoespecies, de las cuales 129 fueron identificadas a nivel de especie en 42 familias. El mayor número de reclutas ocurrió en bosques maduros comparados con bosques tempranos y su supervivencia fue mayor en los bosques maduros.

Conclusiones: Documentamos la progresiva simplificación y homogenización en la composición florística y el efecto generalizado de los humanos en las regiones tropicales.

Palabras clave: agricultura trashumante, heterogeneidad del hábitat, mayas lacandones, paisajes forestales, perturbación humana, selva alta perennifolia.

${ }^{1}$ El Colegio de la Frontera Sur, Departamento de Conservación de la Biodiversidad, 29290 San Cristóbal de Las Casas, Chiapas, Mexico.

${ }^{2}$ Universidad Nacional Autónoma de México, Facultad de Ciencias, 04510 Cd. Mx., Mexico.

${ }^{3}$ University of Central Florida, Department of Biology, 4000 Central Florida Boulevard, 32816 Orlando, Florida, USA.

${ }^{4}$ Author for correspondence: pedro.quintana-ascencio@ ucf.edu
Received: September 28, 2019

Reviewed: February 24,2020

Accepted by Moisés Méndez Toribio: April 13, 2020.

Published Online first: May 21, 2020.

Published: Acta Botanica Mexicana 127 (2020).

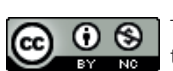

cial Licence (CC BY-1)
This is an open access article under the Creative Commons 4.0 Attribution-Non commerBY-NC 4.0 International).
To cite as:

Carrillo Arreola, F., P. F. Quintana-Ascencio, N. RamírezMarcial and M. González-Espinosa. 2020. Seed rain and establishment in successional forests in Chiapas, Mexico. Acta Botanica Mexicana 127: e1618. DOI: 10.21829/ abm127.2020.1618

e-ISSN: 2448-7589 


\section{Introduction}

During the second half of the $20^{\text {th }}$ century, extensive land clearing for the establishment of agricultural fields and pastures for livestock along with significant changes in agricultural practices decreased, fragmented and altered at growing rates forests in most tropical regions of the world (Gómez-Pompa et al., 1972, 1974; Janzen 1973, 1983, 1986; Kellman et al., 1998; Dirzo and Raven 2003; Brook et al., 2008; Bradshaw et al. 2009; Wright, 2010). Most current remnant tropical forests occur within protected areas surrounded by complex mosaics of vegetation with variable degrees of conservation and transformation by humans (Ricketts, 2001; Vandermeer and Carvajal, 2001; Vieira et al., 2008; Laurance et al., 2014; Chazdon, 2014). These heterogeneous landscapes include a large proportion of the world's biodiversity which is increasingly threatened by changes in community composition, structure and dynamics, with subsequent alteration of their functioning and biogeochemical cycles (Medellín, 1994; Huston, 1994; Grubb, 1996; Lindenmayer and Fisher, 2006). Understanding the ecological consequences of forest habitat degradation and fragmentation on forest landscape dynamics is fundamental to design better agricultural, management and forest conservation practices (Harrison and Bruna, 1998; Chapman et al., 2003; Lindenmayer and Fisher, 2007; Krupnick, 2013).

The ecological changes in southeastern Mexico exemplify the consequences of social and economic policies implemented in many tropical regions of the world. De Vos (2002) documents the changes during the last 150 years in the use of natural resources in the Selva Lacandona rainforest, in eastern Chiapas. The harvest of timber from the tropical rainforest in this region was the dominant activity until the end of the first half of the $20^{\text {th }}$ century. These exploitations concentrated almost exclusively on the extraction of valuable timber (mostly mahogany and tropical red cedar) and few other resources such as chewing-gum base but maintained the vegetation cover. At the beginning of the second half of the century, the Mexican government provided private enterprises with extensive areas and peasants with small parcels and initiated significant changes in the environment through an extensive colonization policy that brought people from many other regions of the country (de Vos, 2002). The new landholders deforested extensive areas for agriculture (both traditional and non-traditional) and cattle ranching compromising subsequent forest regeneration (Ochoa-Gaona et al., 2007). Forest habitat alteration and fragmentation increased at faster rates in most of the region except in the Montes Azules Biosphere Reserve (INE, 2000).

In the same decades, the region underwent major cultural changes. The traditional slash-and-burn milpa agricultural system of the local Maya Lacandon inhabitants has also been increasingly replaced with intensive agricultural practices for monocultures and pastures (Barrera et al., 1977; Levy-Tacher et al., 2002). The indigenous Lacandon Maya traditional milpa farming is based on slashing and burning to provide clearings in which crops can grow (Nations and Nigh, 1980; Nigh, 2008; Nigh and Diemont, 2013). This swidden system maintains significant larger areas vegetated since it is based in polycultures including many native woody species, and requires long fallow periods during which nutrients accumulate in the vegetation and soil, weeds are controlled, and soil properties are rehabilitated (Cowgill, 1962; Reina, 1967; Douterlungne et al., 2010, 2013). Medellín and Equihua (1998) documented in areas with large forest remnants that mammalian species richness did not differ between forests and old milpa fields and argued that traditional Maya-Lacandon use of the land in the form of small agricultural plots embedded in a large forest matrix can increase spatial heterogeneity and promote mammal diversity.

Seed dispersal and recruitment are critical demographic processes affecting species abundance and distribution (Zang et al., 2007). Habitat fragmentation limits seed dispersal affecting species distribution, local population viability and community structure (Schupp and Fuentes, 1995; Harms et al., 2000; Howe and Miriti, 2004; Hampe et al., 2008), decreasing the functionality of habitat corridors among landscape components (Levey et al., 2005; Damschen et al., 2006). Habitat fragmentation also affects seedling recruitment and survival through its effects on patch size, extent of borders, and habitat quality (McEuen and Curran, 2004; Cordeiro et al., 2009). These effects are not homogeneous across species and alter species interactions, community composition and structure, and landscape configuration and functionality (Damschen et al., 2006; Herrera and García, 2010). 
Our aim was to compare the arrival of propagules and their recruitment in tropical successional communities surrounded by habitat matrices with contrasting degrees of human disturbance. We are interested in understanding the potential ecological impact of policies directed to increase expansion of contiguous pastures and commercial agriculture in areas where more scattered traditional swidden agriculture was practiced. A comprehension of the ecological dynamics of agricultural traditional systems and their change provides critical information for the evaluation of current development practices and the design of sustainable use of resources (Nations and Nigh, 1978, 1980; Nigh, 2008; Nigh and Diemont, 2013; Levy-Tacher et al., 2012; Ortega-Álvarez et al., 2019). Specifically, we estimated seed rain and recruitment variation in communities that ranged from mature forests to agricultural fields and pastures within vegetation matrices dominated by old-growth forests or an array of human created habitats.

\section{Methods}

\section{Study sites}

Our study was performed in the buffer zone at the border of the Montes Azules Biosphere Reserve, Selva Lacandona, Chiapas, Mexico, centered in the Maya Lacandon homesteads of Lacanjá-Chansayab and Bonampak-Bethel $\left(16^{\circ} 46^{\prime} \mathrm{N}, 9^{\circ} 08^{\prime} \mathrm{W}, 350-400 \mathrm{~m}\right.$ elevation). Climate is warm-humid with an average annual temperature of 25$27^{\circ} \mathrm{C}$ and an annual rainfall of $180-220 \mathrm{~cm}$ (García, 1987). Precipitation is concentrated ( $>80 \%$ ) between summer and mid-fall (June to October). Remnants of tropical rainforest occur at basins and lower mountain rainforest on hills (Breedlove, 1981; Pennington and Sarukhán, 2005). The vegetation is characterized by a mixture of pastures, milpa fields (traditional land use of Maya Lacandon people with multiple crops including corn, squash, yuca and beans), early successional forests and mature forests (Quintana-Ascencio et al., 1996). We have a concurrent study of the dynamics of seed banks at the same sites (Quintana-Ascencio et al., 1996).

\section{Seed traps}

There was a gradient of forest transformation with larger and better-preserved forest stands near the Bonampak archaeological site and west of Lacanjá-Chansayab, and secondary forest stands, early successional forests, milpa fields and pastures concentrated around the Lacandon dwellings. We established 14 seed traps in each study vegetation association at these two localities: Bonampak-Bethel and Lacanjá-Chansayab ( 2 sites $\times 6$ habitats $\times 14$ traps; $n=$ 168 total; Fig. 1). We used information from local peasants to select study sites and negotiated with them the access to the sites.

We sampled in six successional communities (also described in Carrillo Arreola, 1992 and Quintana-Ascencio et al., 1996):

1. Agriculturally improved pastures without grazing: this community is maintained by periodic fires during February and March. In 1990, it covered approximately 3\% of the study region. It comprised a minor area in the study sites ( $5 \%$; area estimates based on Fig. 1).

2. Milpa surrounded by other milpa fields and early successional forests. Mixtures of corn, squash, beans and other annual and perennial crops are sown after the large woody species are cut and fire is applied in the remaining local community. Local peasants clear these forests at least every 10-20 years to reduce vegetation cover, enrich soils with ashes and reduce weed infestation.

3. Early successional forests with 5-15 years since abandonment: these are dense woody communities dominated by shrubs and fast-growing small trees characterized by associations of Trichospermum galeottii (Turcz.) Kosterm., Cecropia spp., Ochroma pyramidale (Cav. ex Lam.) Urb. and Piper spp. This habitat comprised $<10 \%$ of the area in the study region.

4. Mid-successional forests: these are more complex forest stands with large individuals ( $>10 \mathrm{~m}$ height) of early or mid-successional tree species such as Dendropanax arboreus (L.) Decne. \& Planch., Alchornea latifolia Sw., and Spondias mombin L. in the canopy ( 10\% of the area).

5. Mature forests: we chose forest stands far from human dwellings with tree strata clearly defined, diverse tree species and with average canopy >20 m height ( 75\% of the area).

6. Milpa fields within forest matrix: these communities were traditional multiple crop fields $<1$ ha in area within a matrix of forest that were cleared in preparation 


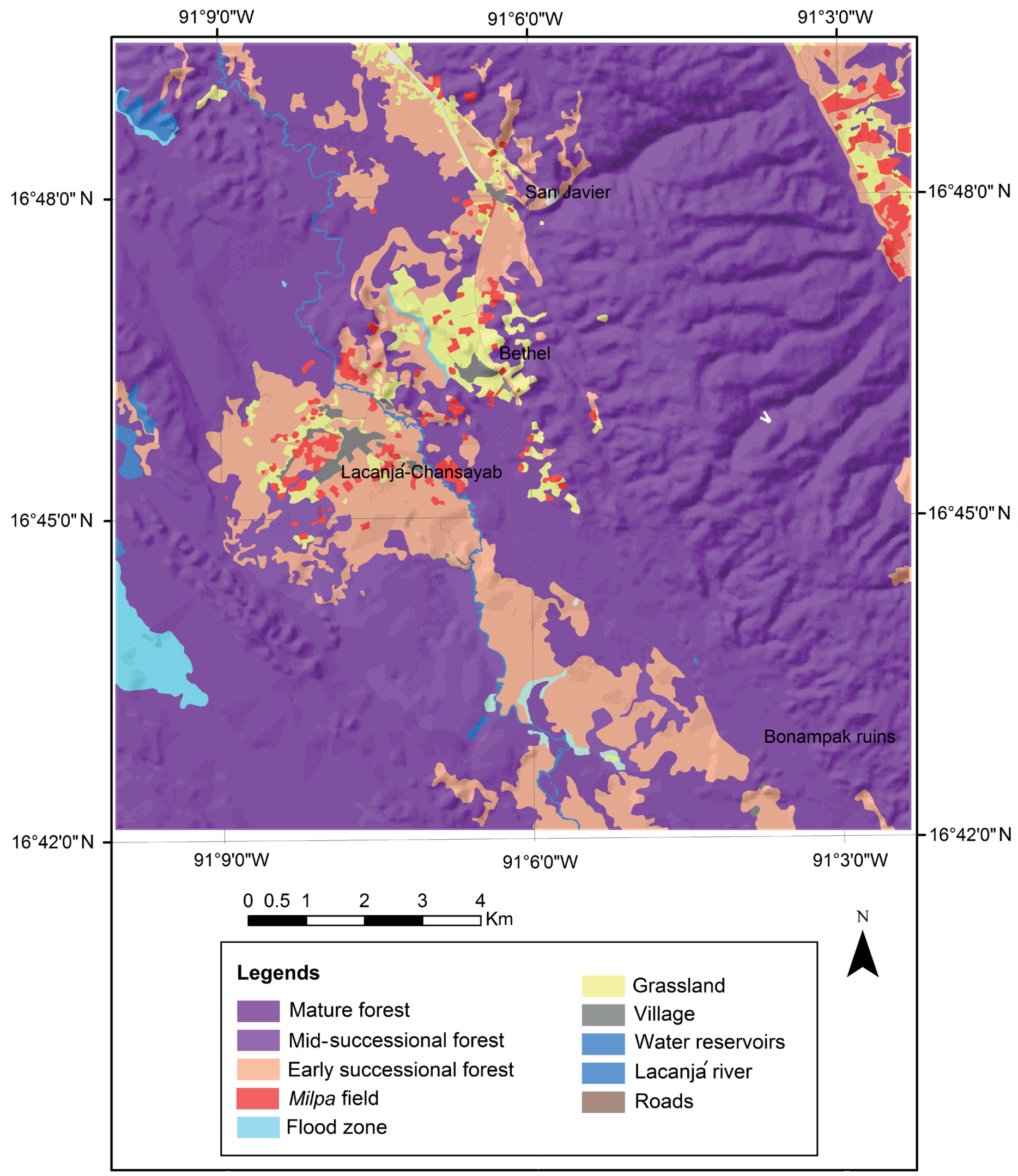

Figure 1: Map of the study sites in the Maya Lacandon homesteads of Lacanjá-Chansayab and Bonampak-Bethel, Chiapas, Mexico. 
for planting just before the start of our study. We set traps in milpa fields within the forest matrix: seven traps were randomly located along the four milpa sides approximately $5 \mathrm{~m}$ from the forest border, the other seven in the center at least $>20 \mathrm{~m}$ from the forest border. Both types of milpa fields together encompassed $<2 \%$ of the study area.

In July 1990, we randomly distributed 14 seed traps in each replicated successional community. In each sampling station, we deployed a funnel-shaped seed trap made of tricot $(50 \times 50 \mathrm{~cm})$ supported by a woody frame at $50 \mathrm{~cm}$ height. Trap content was collected in paper bags approximately every 40-60 days in August, October and November 1990, and February, April, May and July 1991. Bags were transported within 10 days to a laboratory at El Colegio de la Frontera Sur (ECOSUR), San Cristóbal de Las Casas, Chiapas. Branches and leaves were discarded and all other material screened under a dissection microscope (Leica MZ6 stereomicroscope, Heerbrugg, Switzerland). Seeds were separated by morphospecies identified with a serial number and kept in cellophane bags for botanical determination. Damaged traps were replaced as needed. Traps in pastures, milpa fields and one of the early successional forests at Lacanjá-Chansayab were burned after prescribed fires performed by local farmers $(<2$ per site and evaluation, total 8). Samples were pooled by replicated community to estimate composite annual estimates of seed density (abundance $\mathrm{m}^{-2}$ ) and composition. We adjusted estimates as necessary to account for lost samples. Seed taxonomic identity was attained using a reference catalog from plants collected around the study sites and deposited at the herbarium in the Colegio de la Frontera Sur, San Cristóbal de Las Casas, Chiapas, and in the seed catalogue at the Estación Biológica Tropical "Los Tuxtlas", Veracruz, Universidad Nacional Autónoma de México (G. Ibarra-Manríquez and S. Sinaca, pers. communication).

\section{New recruits' plots}

In August and October 1990 we established 90 ( 2 sites $\times$ 3 habitats $\times 15$ quadrats; $n=90$ ) permanent observation plots $(0.5 \times 2.0 \mathrm{~m})$ to monitor abundance of seedlings and juvenile plants $(<0.5 \mathrm{~m})$ in the three different tree and shrub dominated vegetation associations (mature forest, mid-successional forest and early successional forest) in each location. In each replicated forest community we randomly established the 15 plots marked in the corner with wooden sticks. Plots were visited every four months for a year. Monitoring of plots at Bonampak-Bethel was two months behind those at Lacanjá-Chansayab. We identified, mapped and counted every plant $<0.5 \mathrm{~m}$ height within the plot except prostrated plants (mostly Araceae, and other climbing herbs).

\section{Analysis}

Seeds were divided according to their species life form (herbs, vines, lianas, shrubs and trees) and size ( $<2 \mathrm{~mm}, 2-6$ $\mathrm{mm}$ and $>6 \mathrm{~mm}$ diameter). We recognized the life form of plants $<0.5 \mathrm{~m}$ height in the plots. We assessed the significance of differences in abundance of seed assemblages between communities, months and localities with Kruskal-Wallis tests (Potvin and Roff, 1993), and the significance of differences in abundance of plant assemblages between communities and months with Monte Carlo methods (Manly, 1991), because data did not meet the assumptions of parametric tests. For the Monte Carlo tests we randomized 1000 times among communities for each species keeping fixed their rows (species) totals per evaluation. We evaluated dissimilarity based on species presence/absence for seed and plant assemblages among communities in different study sites with Non-metric Multidimensional Scaling (NMS) with Bray-Curtis dissimilarity (Sörensen's index) and a random starting configuration. The final configuration of the ordinations was evaluated with 1000 permutations and both had a $P<0.001$ that similar stress values could happen by chance. Two dimensions were included in the ordination of seed assemblages after assessing the stability. Only one dimension was included for plant assemblages. We conducted analyses in R version 2.7.2 (R Core Team, 2013). We assessed differences between two areas defined by the Lacandon Maya people and successional communities pooling data within each plant association sampled.

\section{Results}

\section{Seed rain}

Overall and after a year of monitoring (August 1990-July 1991) we collected $\sim 13,600$ seeds of 144 species belonging to 48 botanical families. Rubiaceae, Fabaceae, Moraceae 
(includes Cecropia spp.), Araceae, Arecaceae, Piperaceae, and Poaceae comprised $32 \%$ of the species (Appendix 1). Mid-successional and mature forests had the highest species richness (60-72 species), early successional forests and milpa fields were intermediate (17-44) and pastures had the lowest species richness (11-14; Appendix 1; Fig. 2). Overall seed densities were highest in the center of the milpa fields within a forested matrix in Bethel-Bonampak ( 8500 seeds $\mathrm{m}^{-2}$ ), in the mature forest ( 7400 seeds $\mathrm{m}^{-2}$ ) and the early successional forest ( 6200 seeds $\mathrm{m}^{-2}$ ) in Lacanjá-Chansayab, and lowest in the milpa fields of Bethel-Bonampak ( 1700 seeds $\mathrm{m}^{-2}$ ), the center of the milpa within a matrix of forest in Lacanjá-Chansayab ( 1000 seeds $\left.\mathrm{m}^{-2}\right)$, and in the pasture in Bethel-Bonampak ( 100 seeds $\mathrm{m}^{-2}$; Table 1 ).

There was seasonal variation in the number of species and seed density (Kruskall-Wallis $H>19, P<0.004$, for both contrasts), but there were no clear differences among localities $(H=0.49, P=0.48)$. Number of species was lowest during the rainy season (August-October) and highest at the end of the dry season (April-May; Fig. 3). There was a larger change among seasons in number of species captured in the forests than in early successional forests and milpa fields. Pastures had the lowest seasonal contrast in the number of species (Fig. 3). Number of seeds of tree species was highest in July, coinciding with the start of the rainy season, while seeds of herbaceous species peaked in April at the end of the dry season. Seeds of shrubs did not show a marked variation across the year (Fig. 4).

Seeds of different life forms varied across successional communities. Of the 144 species recorded in our seed collection 42 were trees, 25 herbs, 21 shrubs, 19 vines, and 40 could not be determined. Seeds of trees and vines were frequent in forest communities and milpa fields surrounded by forests, and scarce or absent in open communities in disturbed areas. Seeds of shrubs were more abundant in early successional forests and milpa fields in disturbed areas. Seeds of herbaceous species were most abundant in the milpa fields and in early successional forests but were frequent in all communities.

The seed rain was dominated by few species (Table 1). Tree species in the genera Brosimum Sw., Cecropia Loefl. and Ficus L. (included here all three within the Moraceae) contributed with $22-76 \%$ of the seeds in the forests, $13-81 \%$ in disturbed habitats surrounded by forests, $11-33 \%$ in the

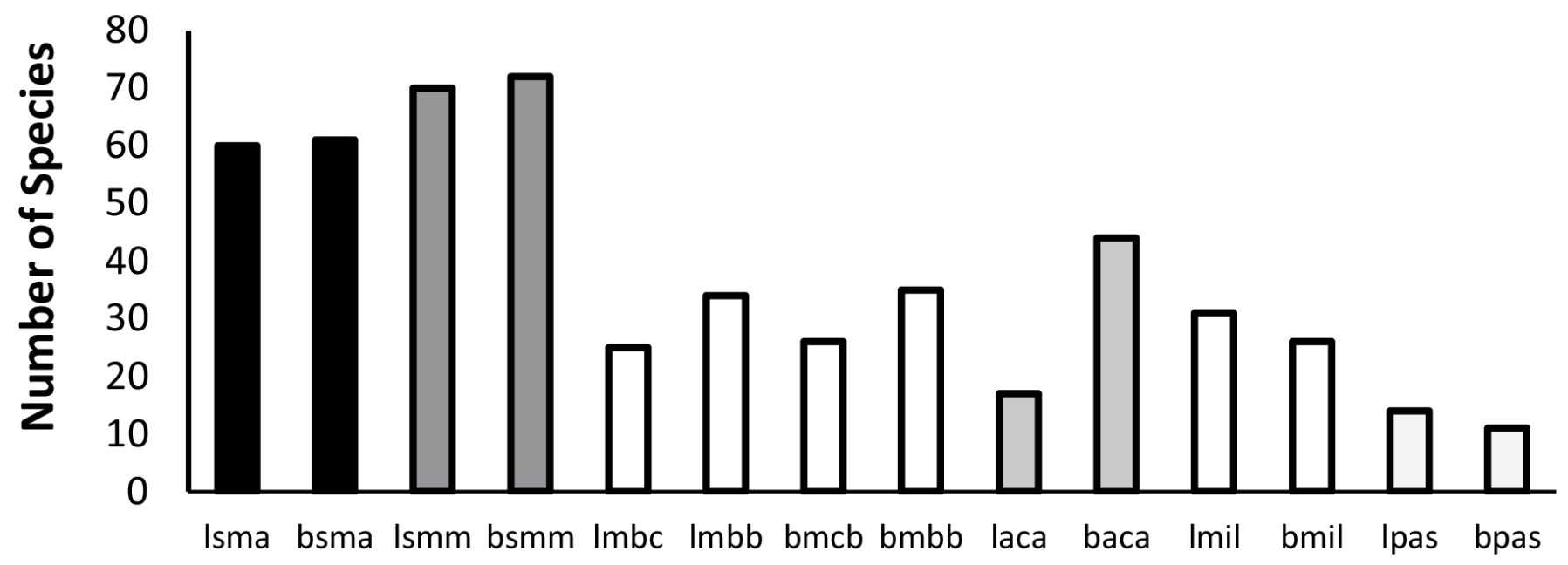

Figure 2: Total number of species per successional condition at the Selva Lacandona, Chiapas, Mexico (August 1990-July 1991). Lacanjá-Chansayab = I; Bonampak-Bethel= b; Vegetation associations: Mature forests = sma; Mid-successional forests = smm; Center of milpa field within forests = mcb; Border of milpa fields within forests = mbb; Early-successional forests = aca; Milpas within disturbed areas = mil; pastures = pas. Habitat perturbation increased in habitats represented by columns with lighter shades. 
Table 1: Percent contribution of the most common species to the total number of seeds collected in six successional communities in the Selva Lacandona, Chiapas, Mexico (August 1990-July 1991). Lacanjá-Chansayab = I; Bonampak-Bethel = b; Successional communities: Mature forests = sma; Mid-successional forests = smm; Center of milpa field within forests = mcb; Border of milpa fields within forests = mbb; Early-successional forests (fallows) = aca; Milpas within disturbed areas = mil; grasslands = pas. ${ }^{*}$ exotic .

\begin{tabular}{|c|c|c|c|c|c|c|c|c|c|c|c|c|c|c|}
\hline Species & Isma & bsma & Ismm & bsmm & Imcb & Imbb & bmcb & bmbb & laca & baca & Imil & bmil & Ipas & bpas \\
\hline Brosimum sp. & & & & & & & & 7.1 & & & & & & \\
\hline Cecropia spp. & 49.4 & & 39.1 & 9.9 & & 1.6 & & & 32.6 & 7.0 & & & & \\
\hline Ficus aurea Nutt. & 14.9 & 11.6 & 1.9 & & 12.9 & 38.0 & 51.0 & 23.4 & & & 2.4 & 2.4 & & \\
\hline Ficus insipida Willd. & 6.8 & 16.1 & 2.6 & 1.2 & & & & & & 4.5 & & & & \\
\hline Ficus jimenezii Standl. & 4.6 & 3.2 & 9.2 & 10.6 & & & 29.7 & & & & & & & \\
\hline Heliocarpus spp. & & 23.3 & 5.0 & & 8.4 & & & & & & & & & \\
\hline Andropogon bicornis $\mathrm{L}$. & & & & & & & & & & & & & 8.2 & \\
\hline Hyparrhenia rufa*(Nees) & & & & & & & & & & & & & & \\
\hline Stapf & & & & & & & & & & & & & 19.2 & \\
\hline Paspalum paniculatum L. & & & & & & & & & & & & & 59.4 & \\
\hline Paspalum virgatum $\mathrm{L}$. & & & & & & & & & & & & & & 49.2 \\
\hline Bidens spp. & & & & & & & & & & & 10.9 & & & \\
\hline Undetermined spp. & 12.6 & 31.2 & 32.4 & 56.6 & 64.0 & 47.9 & 15.3 & 32.4 & 11.5 & 16.6 & 28.6 & 59.3 & 8.2 & \\
\hline Euphorbia heterophyla L. & & & & & & & & & & & & 15.5 & & 7.6 \\
\hline Iresine spp. & & & & & & 2.2 & & 24.0 & & & 9.0 & & & 5.5 \\
\hline Piper sp. 1 & & & & & & & & & 25.1 & 24.1 & 10.9 & 2.1 & & 11.2 \\
\hline Piper sp. 2 & & & & & & & & & 22.7 & 25.7 & 29.0 & 2.9 & & 16.6 \\
\hline Accumulated \% & 88 & 85 & 90 & 78 & 85 & 90 & 96 & 87 & 92 & 78 & 91 & 82 & 95 & 90 \\
\hline Total seeds $\mathrm{m}^{-2}$ & 7453 & 1757 & 5843 & 1448 & 1013 & 2562 & 8528 & 2338 & 6225 & 5302 & 7344 & 1669 & 2800 & 132 \\
\hline
\end{tabular}

early successional forests, less than $3 \%$ in the milpas within disturbed matrix, and were absent in the pastures. Seeds of Piper spp. were only found in early successional forests and in milpa fields, where they contributed with $2-25 \%$. Seeds of Asteraceae were relatively abundant in all communities (8.2-57\%). Exotic invasive grasses were exclusive of pastures, where they contributed with (49-87\%).

Distribution of seeds in the three size groups varied among successional communities and seasons (KruskallWallis $H>55, P<0.001$, for both contrasts), but there was no clear evidence of heterogeneity among localities $(H=0.08$, $P=0.77)$. In our sample, 38 species had seeds $<2 \mathrm{~mm}, 76$ were 2-6 $\mathrm{mm}$, and 28 were $>6 \mathrm{~mm}$ in diameter. The smallest seeds were relatively homogeneously distributed across communities. Seeds of intermediate size were more abundant in early successional forests than in forests and almost absent in open communities. The largest seeds were most abundant in the border of the forest with the milpa fields in the forest matrix, followed by forests, early successional forests, and were scarce in disturbed and open habitats. The peak of dispersal of small and large-sized seeds happened during the end of the dry season. Mid-sized seeds did not show a clear seasonality of dispersal.

NMS ordination indicated the dissimilarity among assemblages (axis 1 eigenvalue $=0.99, P=0.02$, axis 2 eigenvalue $=0.03, P=0.04 ;$ Fig. 5 ). This ordination explained 0.896 of the variance. Axis one summarized most of the dissimilarity variation among successional communities studied. The dissimilarity pattern was consistent between Lacanjá-Chansayab and Bonampak-Bethel. Mature and mid-successional forest communities were highly similar from each other and formed a cluster. Milpa fields within 
(A)

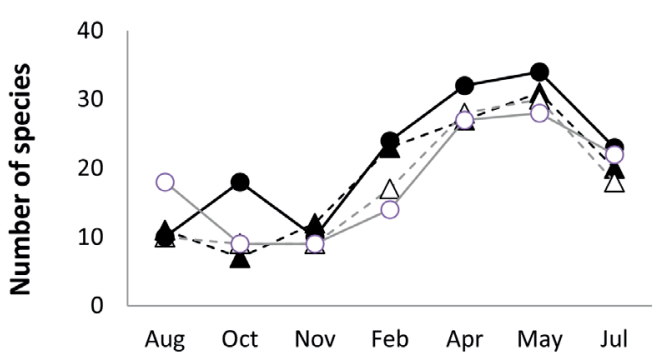

B

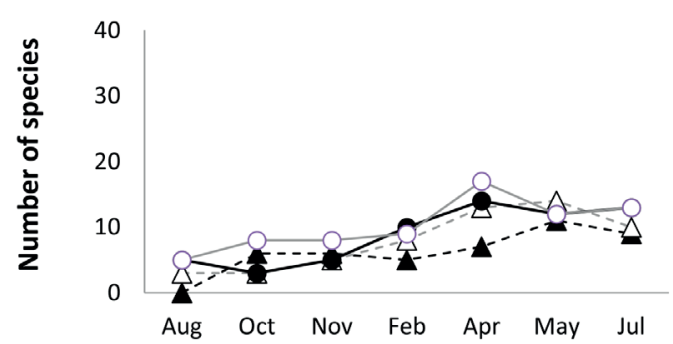

(C)

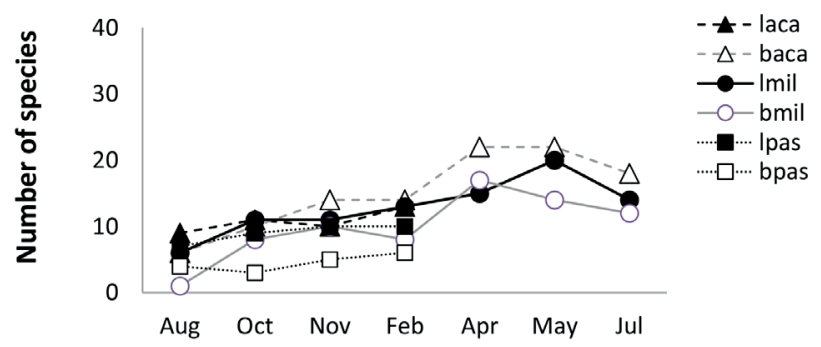

Figure 3: Number of species per month and successional condition in the Selva Lacandona, Chiapas, Mexico (August 1990-July 1991). A. mature (ma) and mid-successional ( $\mathrm{mm}$ ) forest; B. center (cb) and border (bb) of the milpa surrounden by forest; $C$. early successional forest (aca), milpas (mil) ans pastures (pas). Lacanjá-Chansayab = l; Bonampak-Bethel= b; Vegetation associations: Mature forests $=$ sma; Mid-successional forests $=$ smm; Center of milpa field within forests $=$ mcb; Border of milpa fields within forests $=\mathrm{mbb}$; Early-successional forests $=\mathrm{aca}$; Milpas within disturbed areas $=$ mil; pastures $=$ pas.

a matrix of forest were closest to the forest communities and in a central position among forests, early successional forests, and milpa fields in the disturbed habitat matrix. In the ordination space, associations in the borders of the milpa surrounded by forest were closest to the forests. Associations in the milpa fields within the matrix of disturbed habitats were equally distant from the early successional

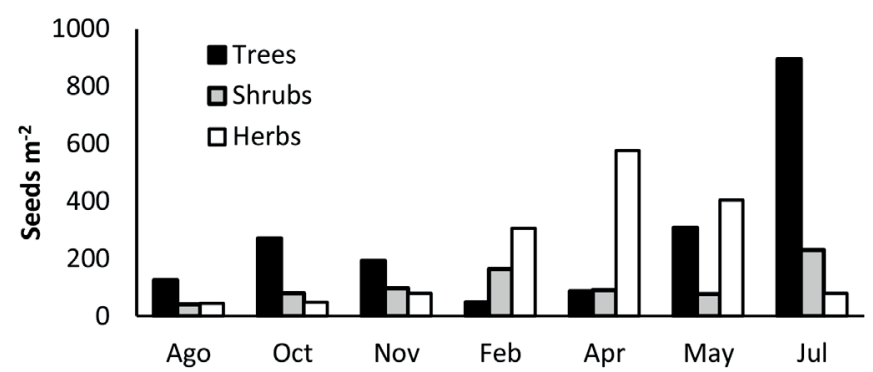

Figure 4: Seed density per month by life-form in the Selva Lacandona, Chiapas, Mexico (August 1990-July 1991; vines and unknown species had small contributions and were not plotted).

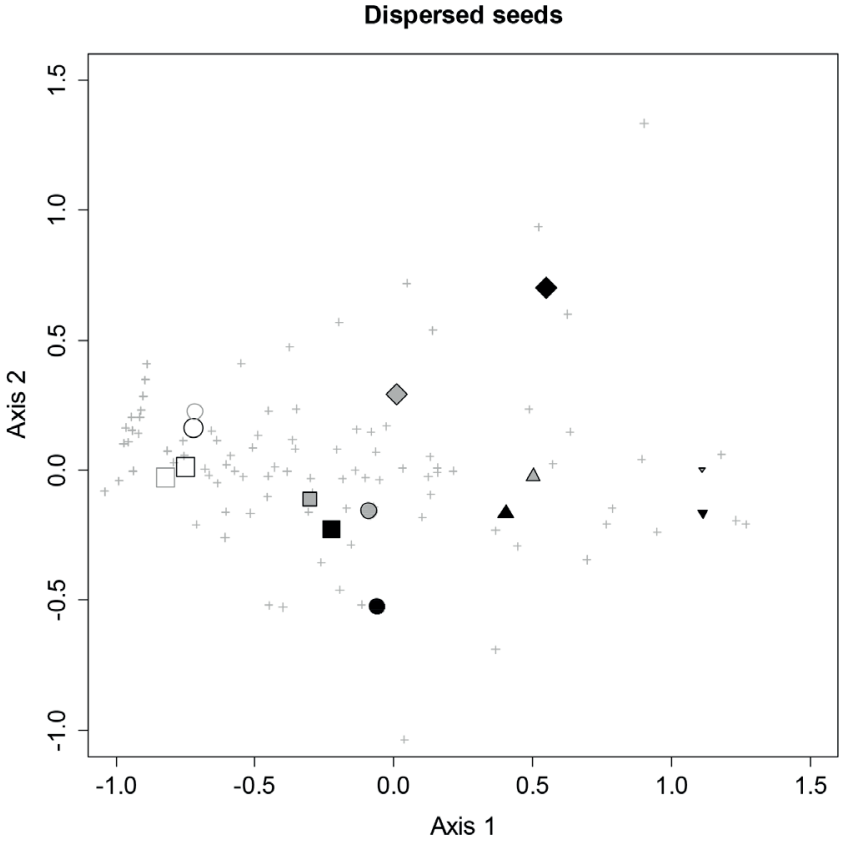

Figure 5: Non-metric multidimensional scaling with Bray-Curtis dissimilarity (Sörensen's index) for associations of seeds of species in successional communities in Lacanjá-Chansayab, Chiapas, Mexico. Black symbols: Bonampak-Bethel; Gray symbols: Lacanjá-Chansayab; Vegetation associations, open circles: Mature forests; open squares: Mid-successional forests; filled squares: Border of milpa fields within forests; filled circles: Center of milpa field within forests; diamonds: Early-successional forests; up-pointed triangles: Milpas within disturbed areas; down-pointed triangles: pastures; Size of the site symbols was adjusted by the proportion of tree species in the sample; crosses: species.

forests and milpa in the forests. Pastures were the most distant from all other communities. Axis two mostly summarized differences among early successional forests and the rest of the communities. 


\section{Establishment of new recruits}

Overall, we recorded $\sim 3416$ new recruits with a height $<0.5$ $\mathrm{m}$ belonging to 238 morphospecies in 48 botanical families, 98 were identified to genus and 76 to species (Appendix 2). Among these plants, the largest number of species occurred in mature and mid-successional forests compared to early successional forests in both locations (Table 2 ). The number of species was higher in the mid-successional and mature forests of Bonampak-Bethel compared to Lacanjá-Chansayab. The number of plants $<0.5 \mathrm{~m}$ in height was highest in the forests and lowest in the early successional forests (Table 2). Plant density was in general higher in the mid-successional and mature forests of Bonampak-Bethel compared to Lacanjá-Chansayab. Survival of plants $<0.5 \mathrm{~m}$ was higher in mid- and late successional forests than in early successional ones (Table 2 ).

Most small plants belonged to a few species. Seedlings of Chamaedorea spp. were abundant in the mid-successional and mature forest communities $(7-11 \%$ of the total number of seedlings in a given community), and rare in early successional forests. Seedlings of Pseuderanthemum verapazense Donn. Sm., an unidentified taxon of Sapindaceae, and an unidentified species were common in the forests of Lacanjá-Chansayab (26-38\%), while seedlings of Ampelocera hottlei (Standl.) Standl., Rinorea guatemalensis (S. Watson) Bartlett, Brosimum alicastrum Sw., Paullinia costata Schltdl. \& Cham., and an unidentified species of Sapindaceae were common in the forests of Bonampak-Bethel (25-41\%). Plants of Iresine spp. were abundant in early successional forests in both locations (17-32\%). Seedlings of Dendropanax arboreus, Piper glabrescens (Miq.) C. DC., and a Heliconia species were abundant in the fallow fields at Lacanjá-Chansayab (22\%), while seedlings of Acalypha diversifolia Jacq., Psychotria pubescens Sw. and a grass were common in the fallow fields at Bonampak-Bethel (28\%). We recognized the life form of the small plants for 143 species: three were annual herbs, 30 perennial herbs, 15 vines, nine ferns, 44 shrubs, 8eight palms, and 32 trees. Seedlings of trees, palms and vines were more abundant in mid- and late successional forests. Small individuals of shrubs were common in all forest stands. Herbs were more abundant in early successional forests.

Table 2: Density of plants $<0.50 \mathrm{~cm}$ tall ( $\mathrm{m}^{-2} \pm$ standard error), number of species per evaluation and total (in three evaluations) and plant survival of plants in control plots at three replicated forested successional communities in the Selva Lacandona, Chiapas, Mexico (August 1990-June 1991). Lacanjá-Chansayab = I; Bonampak-Bethel= b; Successional communities: Mature forests = sma; Mid-successional forests = smm; Early-successional forest (fallows) = aca. Monitoring of plots at Bonampak-Bethel was two months behind those at Lacanjá-Chansayab. We do not have evidence of significant differences between communities with the same letter in the same column after Monte Carlo tests with 1000 simulations.

\begin{tabular}{|c|c|c|c|c|c|c|c|c|}
\hline & & Sampling months & & & Plant survival ( \pm sta & ndard error) & & \\
\hline Site & Variable & $\begin{array}{c}\text { August/October } \\
1990\end{array}$ & $\begin{array}{c}\text { December/ } \\
\text { February }\end{array}$ & $\begin{array}{c}\text { April/June } \\
1991\end{array}$ & Aug/Oct-Dec/Feb & Dec/Feb-Apr/Jun & Aug/Oct-Apr/Jun & $\begin{array}{r}\text { Total of } \\
\text { species }\end{array}$ \\
\hline Isma & plants $\mathrm{m}^{-2}$ & $14.5(1.03) b$ & $16.0(1.22) b$ & $15.9(1.56) b$ & $0.43(0.07) \mathrm{c}$ & $0.46(0.07) \mathrm{c}$ & $0.30(0.06) b$ & \\
\hline bsma & plants $\mathrm{m}^{-2}$ & $18.5(0.85)$ a & $23.4(0.95)$ a & $36.1(3.62) a$ & $0.63(0.05) \mathrm{a}$ & $0.32(0.05) \mathrm{e}$ & $0.33(0.05) b$ & \\
\hline Ismm & plants $\mathrm{m}^{-2}$ & $18.1(1.33) \mathrm{a}$ & $16.7(1.12) b$ & $18.3(1.45) b$ & $0.54(0.06) b$ & $0.50(0.07) b$ & $0.43(0.06) a$ & \\
\hline bsmm & plants $\mathrm{m}^{-2}$ & $20.6(1.07) a$ & $25.9(1.07) \mathrm{a}$ & $33.6(2.12) \mathrm{a}$ & $0.53(0.06) b c$ & $0.61(0.06) a$ & $0.36(0.05) b$ & \\
\hline laca & plants $\mathrm{m}^{-2}$ & $7.67(1.09) \mathrm{c}$ & $10.9(1.01) c$ & 17.6 (1.68) b & $0.47(0.07) \mathrm{c}$ & $0.40(0.08) d$ & $0.26(0.07) c$ & \\
\hline baca & plants $\mathrm{m}^{-2}$ & $9.07(1.03) \mathrm{c}$ & $10.5(1.19) \mathrm{c}$ & 15.5 (1.56) b & $0.37(0.08) d$ & $0.38(0.07) d$ & $0.23(0.06) c$ & \\
\hline Isma & species & $43 b c$ & $45 b$ & $40 \mathrm{~b}$ & & & & $69 \mathrm{~b}$ \\
\hline bsma & species & $66 a$ & $68 \mathrm{a}$ & $61 \mathrm{a}$ & & & & $96 a$ \\
\hline Ismm & species & $53 a b$ & $58 a b$ & $53 a b$ & & & & $74 \mathrm{~b}$ \\
\hline bsmm & species & $55 a b$ & $68 \mathrm{a}$ & $64 \mathrm{a}$ & & & & 96 a \\
\hline laca & species & $34 \mathrm{c}$ & $42 \mathrm{~b}$ & $45 \mathrm{~b}$ & & & & $67 \mathrm{~b}$ \\
\hline baca & species & $28 \mathrm{c}$ & $31 b$ & $47 \mathrm{~b}$ & & & & $59 \mathrm{~b}$ \\
\hline
\end{tabular}


Dissimilarity in floristic composition among locations and vegetation associations was highest between mid-successional and mature forests and early successional forests (>0.91 for all comparisons), and lowest between mid- and late successional forests within locations $(0.43$ and 0.47 for Bonampak and Lacanjá-Chansayab, respectively). Distance between locations was 0.67 for early successional forests, 0.60 for mid-successional and 0.68 for mature ones. Distances between mid-successional and mature forests across localities were 0.54 and 0.66 .

\section{Discussion}

We document pervasive effects of the increasing predominance of humanized landscapes in the buffer zone of the Montes Azules Biosphere Reserve, Selva Lacandona, Chiapas, Mexico. We observed a significant decline in species richness and a change in dominance of life forms in the seed rain assemblage along the floristic successional gradient. At the extremes, mature forest included seeds of diverse tree species while the assemblage in pastures was dominated by seeds of a few grasses, mostly introduced exotic species. Areas characterized by intensive agriculture and pastures nearby human dwellings were associated with the most simplified and homogeneous floristic composition of seed assemblages. Seeds of tree species were present in milpa fields surrounded by forest but were absent in milpa in humanized environments where there was a dominance of seeds of generalist and widespread herbaceous species, many of them exotic species. The arrival of tree seeds into milpa fields surrounded by forests promotes faster recovery of the forest (Gómez-Pompa and Vázquez-Yanes, 1981).

Increasing dominance of open and disturbed habitats facilitates dispersal and colonization by invasive and weedy species (Uhl et al., 1981; Uhl and Clark, 1983; Saulei and Swaine, 1988; Drake, 1998). Because most of these herbaceous species have long distance dispersal and long-lived seed banks, as their seeds accumulate in the soil of mature remnant forest stands within the humanized mosaic where they are readily available to establish after disturbances (Guevara and Gómez-Pompa, 1972; Demel and Granström, 1995; Quintana-Ascencio et al., 1996; López-Toledo and Martínez-Ramos, 2011). This compositional change in the seed bank can increase the interference of these species with crops in recently prepared milpa fields and may alter successional sequences (del Castillo and Pérez-Ríos, 2008). Notwithstanding the observed influence of the humanized landscapes on the recovery of the original associations of the tropical rainforest, it should be noted that we do not expect to have a complete representation of the tree species composition in the forest based on seeds arriving to our traps within a year. Whether the temporal and methodological limitations of our study are sufficient to make our point regarding the pernicious effects of extensive humanized habitats, will depend on future long-term studies in the same region aimed to assess a possible extinction debt in the coming decades (Wearn et al., 2012) and the recovery potential contained in widespread secondary growth vegetation (GómezPompa et al., 1972; Chazdon, 2014).

Site successional condition and landscape configuration affected community composition. Species composition of seed dispersal assemblages in the Lacandon rainforest was more similar to species composition of local vegetation than previously reported similarities between soil seed banks and vegetation from a concurrent study (QuintanaAscencio et al., 1996). As it has been documented in other studies in tropical forests (Franklin and Rey, 2007; GomesFreitas et al., 2013; Weerasinghe et al., 2019), small and wind dispersed seeds of generalist herb species dominated seed assemblages in human-controlled environments while large fleshy seeds or fruits of woody species were more common in continuous forest stands or in their border with milpas. Fast decaying seed dispersal kernels of many woody species can help to explain the similarity between seed rain and vegetation (Álvarez-Buylla and Martínez-Ramos, 1990; Drake, 1992; Burrows, 1994). Human impacts on species interactions can alter and reduce dispersal kernels. Seed removal, seed dispersal distances and seed predation processes shape seed dispersal kernels and influence the location and density of seeds deposited (Dirzo et al., 2007). Growing anthropogenic impact including hunting, habitat alteration and fragmentation changes abundance of vertebrates and affects their behavior (Babweteera and Brown, 2010; Bagchi et al., 2011; Bravo, 2012; Brodie and Aslan, 2012; Carrara et al., 2015).

Forest loss and habitat configuration have direct effects on plant recruitment, survivorship and fecundity of many species and indirect long-term negative effects on 
their population viability through decreasing growth rates and loss of genetic variation (Heywood and Iriondo, 2003; Gagnon et al., 2011). Changes in mortality, growth and recruitment and in forest stand structure with succession in a neighboring region in the Selva Lacandona were rapid during the first five years of succession, decreasing rapidly afterwards and negatively related with initial stand basal area, but relatively independent of initial tree density (Van Breugel et al., 2006). Reduced diversity and differences in species composition have been documented between large forest fragments and smaller fragments within humanized habitat mosaics (Arroyo-Rodríguez and Mandujano, 2006). In these impoverished landscapes pioneer, weedy and alien species increase in abundance in the remnant smaller fragments and along forest edges (Tabarelli et al., 2010; Lôbo et al., 2011). Larger borders with agricultural fields and pastures increase risks of seed predation by scatter-hoarding rodents in disturbed forests (Gutiérrez-Granados, 2011). The extent of forest fragments in the Brazilian Amazon influenced seed abundance and composition of soil seed banks and clearly influenced the potential resilience and regeneration of these sites in the event of natural or anthropic disturbances (Sousa et al., 2017).

We found consistent seed rain assemblages among the two studied localities and seasonal variation in the identity, number of species and seed density captured. Patterns of variation in seed number and abundance among successional communities were commensurate between the relatively independent landscapes of Bonampak-Bethel and Lacanjá-Chansayab, strengthening the generality of our findings. We also observed that species richness was significantly higher during the dry season (April-May) and lowest during the rainy season (August-October). Similar seasonal variation in seeds captured has been documented in other tropical rainforests (Sheldon and Nadkarni, 2013). Habitat and life form affected the seasonal abundance and richness of seeds caught. The change in number of species captured was higher in the forests than in early successional forests and milpa fields, while pastures had almost no variation. Peak abundance of seeds of tree species coincides with the start of the rainy season, while seeds of herbaceous species peak during the dry season. Variation in abundance of seeds of shrubs was lower across seasons.
Cumulative replacement of tropical forest and scattered milpa fields by pastures and extensive commercial agriculture that use exotic agrochemicals and intensive soil management will increasingly compromise forest regeneration and conservation of biodiversity. Until recently, forest regeneration neighboring a traditional agricultural landscape has been dependent on the configuration of a highly diverse vegetation matrix. Our results add to prior evidence indicating that progressively smaller forest fragments surrounded by more homogeneous matrices of increasingly simplified habitats will reduce seed exchange of mid- and late successional species among remnant stands and alter environmental conditions necessary for their establishment. Simultaneously, growing abundance of widespread weedy generalist herbaceous species will modify species interactions in recently disturbed and regeneration habitats which will negatively affect recruitment and establishment of late successional species. The traditional Mayan milpa system relies on successional processes restocking soil nutrients and reducing nuisance plants (Collier, 1975; Hernández-Xolocotzi, 1993; Douterlungne et al., 2010; Nigh, 2008; Nigh and Diemont, 2013). Shorter return times associated with intensive agriculture will decrease crop harvesting rates because of changes in vegetation composition and reduction in the accumulation of plant biomass and nutrients. Growing dominance of intensive productive systems hinders the regeneration potential of secondary habitats linked to tropical rainforest and undermines the sustainability of traditional practices and the economic balance of native people in tropical regions.

\section{Author contributions}

MGE, NRM and PFQA designed the study. All the authors participated with field work. FCA built the seed traps and separated the seed samples in the lab. NRM and FCA identified the species. PFQA performed the analyses. All the authors contributed with the writing and edition of the document.

\section{Funding}

This study was financed by Secretaría de Educación Pública and Consejo Nacional de Ciencia y Tecnología (grant ref. no. P220CCOR892485 to MGE). 


\section{Acknowledgements}

We thank the Lacandon Maya communities of Lacanjá-Chansayab and Bethel for their hospitality and collaboration. C. Silva Rhoads (INAH-Chiapas) and local workers allowed the use of facilities under their responsibility at Bonampak. The support provided by Miguel Martínez-Icó and J. M. Mauricio Leguízamo was vital. G. Ibarra Manríquez and S. Sinaca (EBLT-UNAM), S. Ochoa Gaona (ECOSUR) and J. D. García Pérez (CHAPA) assisted with botanical determinations. P. E. Mendoza Hernández and G. Domínguez-Vázquez participated during field work and E. Valencia Barrera elaborated the map. The comments of four anonymous reviewers improved this manuscript.

\section{Literature cited}

Álvarez-Buylla, E. R. and M. Martínez-Ramos. 1990. Seed bank versus seed rain in the regeneration of a tropical pioneer tree. Oecologia 84: 314-325. DOI: https://doi.org/10.1007/ BF00329755

Arroyo-Rodríguez, V. and S. Mandujano. 2006. The importance of tropical rain forest fragments to the conservation of plant species diversity in Los Tuxtlas, Mexico. Biodiversity and Conservation 15: 4159-4179. DOI: https://doi.org/10.1007/ s10531-005-3374-8

Barrera, A., A. Gómez-Pompa and C. Vázquez-Yanes. 1977. El manejo de las selvas Mayas: sus implicaciones silvícolas y agrícolas. Biotica 2: 47-61.

Babweteera, F. and N. Brown. 2010. Spatial patterns of tree recruitment in East African tropical forests that have lost their vertebrate seed dispersers. Journal of Tropical Ecology 26(2): 193-203. DOI: https://doi.org/10.1017/ S026646740999054X

Bagchi, R., C. D. Philipson, E. M. Slade, A. Hector, S. Phillips, J. F. Villanueva, O. T. Lewis, C. H. C. Lyal, R. Nilus, A. Madran, J. D. Scholes and M. C. Press. 2011. Impacts of logging on density-dependent predation of dipterocarp seeds in a South East Asian rainforest. Philosophical Transactions of the Royal Society B 366: 3246-3255. DOI: https://doi.org/10.5167/ uzh-52548

Bravo, S. P. 2012. The impact of seed dispersal by black and gold howler monkeys on forest regeneration. Ecological Research 27(2): 311-321. DOI: https://doi.org/10.1007/ s11284-011-0904-6
Bradshaw, C. J. A., N. S. Sodhi and B. W. Brook. 2009. Tropical turmoil: A biodiversity tragedy in progress. Frontiers in Ecology and the Environment 7(2): 79-87. DOI: https://doi. org/10.1890/070193

Breedlove, D. E. 1981. Flora of Chiapas. Part I: Introduction to the Flora of Chiapas. California Academy of Sciences. San Francisco, USA. 35 pp.

Brook, B. W., N. S. Sodhi and C. J. A. Bradshaw. 2008. Synergies among extinction drivers under global change. Trends in Ecology and Evolution 23(8): 453-460. DOI: https://doi. org/10.1016/j.tree.2008.03.011

Brodie, J. F. and C. E. Aslan. 2012. Halting regime shifts in floristically intact tropical forest deprived of their frugivores. Restoration Ecology 20(2): 153-157. DOI: https://doi. org./10.1111/j.1526-100X.2011.00833.x

Burrows, C. J. 1994. Seed trapping in Ahuriri Summit Bush Scenic Reserve, Port Hills, western Banks Peninsula, 1985-86. New Zealand Journal of Botany 32(2): 183-215. DOI: https://doi. org/10.1080/0028825X.1994.10410367

Carrara, E., V. Arroyo-Rodríguez, J. H. Vega-Rivera, J. E. Schondube, S. M. de Freitas and L. Fahrig. 2015. Impact of landscape composition and configuration on forest specialist and generalist bird species in the fragmented Lacandona rainforest, Mexico. Biological Conservation 184: 117-126. DOI: https://dx.doi.org/10.1016/j.biocon.2015.01.014

Carrillo Arreola, F. 1992. Lluvia de semillas y establecimiento de plántulas en comunidades secundarias de la selva Lacandona, Chiapas, México. Tesis de licenciatura, Facultad de Ciencias. Universidad Nacional Autónoma de México. México, D.F., México. 53 pp.

Chapman, C. A., L. J. Chapman, K. Vulinec, A. Zanne and M. J. Lawes. 2003. Fragmentation and alteration of seed dispersal processes: An initial evaluation of dung beetles, seed fate, and seedling diversity. Biotropica 35(3): 382-393. DOI: https://doi.org/10.1646/02149

Chazdon, R. L. 2014. Second growth: The promise of tropical forest regeneration in an age of deforestation. The University of Chicago Press. Chicago, Illinois, USA.

Collier, G. A. 1975. Fields of the Tzotzil: the ecological bases of tradition in highland Chiapas. University of Texas Press. Austin, USA. $255 \mathrm{pp}$.

Cordeiro, N. J., H. J. Ndangalasi, J. P. McEntee and H. F. Howe. 2009. Disperser limitation and recruitment of an endemic 
African tree in a fragmented landscape. Ecology 90(4): 1030-1041. DOI: https://doi.org/10.1890/07-1208.1

Cowgill, U. M. 1962. An agricultural study of the southern Maya lowlands. American Anthropologist 64(2): 273-286.

Damschen, E. I., N. M. Haddad, J. L. Orrock, J. J. Tewksbury and D. J. Levey. 2006. Corridors increase plant species richness at large scales. Science 313(5791): 1284-1286. DOI: https:// doi.org/10.1126/science.1130098

de Vos, J. 2002. Una tierra para sembrar sueños. Historia reciente de la Selva Lacandona, 1950-2000. Fondo de Cultura Económica. México, D.F., México. 505 pp.

del Castillo, R. F. and M. A. Pérez-Ríos. 2008. Changes in seed rain during secondary succession in a tropical montane cloud forest region in Oaxaca, Mexico. Journal of Tropical Ecology 24(4): 433-444. DOI: https://doi.org/10.1017/ S0266467408005142

Demel, T. and A. Granström. 1995. Soil seed banks in dry Afromontane forests of Ethiopia. Journal of Vegetation Science 6(6): 777-786. DOI: https://doi.org/10.2307/3236391

Didham, R., J. Tykianakis, N. Gemmell, T. Rand and R. Ewers. 2007. Interactive effects of habitat modification and species invasion on native species decline. Trends in Ecology and Evolution 22(9): 489-496. DOI: https://doi.org/10.1016/j. tree.2007.07.001

Dirzo, R. and P. H. Raven. 2003. Global state of biodiversity and loss. Annual Review of Environmental Resources 28: 137-167. DOI: https://doi.org/10.1146/annurev.energy.28.050302.105532

Dirzo, R., E. Mendoza and P. Ortiz. 2007. Size-related differential seed predation in a heavily defaunated Neotropical rain forest. Biotropica 39(3): 355-362. DOI: https://doi. org/10.1111/j.1744-7429.2007.00274.x

Douterlungne, D., E. Thomas and S. I. Levy-Tacher. 2013. Fast-growing pioneer tree stands as a rapid and effective strategy for bracken elimination in the Neotropics. Journal of Applied Ecology 50(5):1257-1265. DOI: https://doi. org/10.1111/1365-2664.12077

Douterlungne, D., S. I. Levy-Tacher, D. J. Golicher and F. RománDañobeytia. 2010. Applying indigenous knowledge to the restoration of degraded tropical rain forest clearings dominated by Bracken fern. Restoration Ecology 18(3): 322-329. DOI: https://doi.org/10.1111/j.1526-100X.2008.00459.x

Drake, D. R. 1992. Seed dispersal of Metrosideros polymorpha (Myrtaceae): A pioneer tree of Hawaiian lava flows. Ameri- can Journal of Botany 79(11): 1224-1228. DOI: https://doi. org/10.1002/j.1537-2197.1992.tb13724.x

Drake, D. R. 1998. Relationship among the seed rain, seed bank and vegetation of a Hawaiian forest. Journal of Vegetation Science 9(1): 103-112. DOI: https://doi.org/10.2307/3237228

Franklin, J. and S. J. Rey. 2007. Spatial patterns of tropical forest trees in Western Polynesia suggest recruitment limitations during secondary succession. Journal of Tropical Ecology 23(1): 1-12. DOI: https://doi.org/10.1017/S0266467406003774

García, E. 1987. Modificaciones al Sistema de clasificación de Köppen. Instituto de Geografía. Universidad Nacional Autónoma de México. México, D.F., México. 246 pp.

Gagnon, P. R., E. M. Bruna, P. Rubim, M. R. Darrigo, R. C. Littell, M. Uriarte and W. J. Kress. 2011. Growth of an understory herb is chronically reduced in Amazonian forest fragments. Biological Conservation 144(2): 830-835. DOI: https://doi. org/10.1016/j.biocon.2010.11.015

Gomes Freitas, C., C. Dambros and J. L. Campana-Camargo. 2013. Changes in seed rain across Atlantic Forest fragments in northeast Brazil. Acta Oecologica 53: 49-55. DOI: https://doi. org/10.1016/j.actao.2013.08.005

Gómez-Pompa, A. and C. Vázquez-Yanes. 1981. Successional studies in the rainforest in Mexico. In: West, D. C., H. H. Shugart and D. B. Botkin (eds.). Forest Succession. Concepts and applications. Springer. New York, USA. Pp. 246-266. DOI: https://doi.org/10.1007/978-1-4612-5950-3_16

Gómez-Pompa, A., C. Vázquez-Yanes and S. Guevara. 1972. The tropical rain forest: A nonrenewable resource. Science 177(4051): 762-765. DOI: https://doi.org/10.1126/science.177.4051.762 Gómez-Pompa, A., A. L. Anaya, F. Golley, G. Hartshorn, D. Janzen, M. Kellman, L. Nevling, J. Peñalosa, P. Richards, C. Vázquez and P. Zinke. 1974. Recovery of tropical ecosystems. In: Farnworth, E. G. and F. B. Golley (eds.). Fragile ecosysytems. Springer. Oxford, UK. Pp. 113-138. DOI: https://doi.org/10.1007/9783-642-86763-7_4

Grubb, P. J. 1996. Rainforest dynamics: The need for new paradigm. In: Edwards, D. S. W. E. Booth and S. C. Choy (eds.). Tropical Rainforest Research-Current Issues. Kluwer. Boston, USA. Pp. 215-234. DOI: https://doi.org/10.1007/978-94-0091685-2_21

Guevara, S. and A. Gómez-Pompa. 1972. Seeds from surface soils in a tropical region of Veracruz, Mexico. Journal of the Arnold Arboretum 53: 312-335. 
Gutiérrez-Granados, G. 2011. Effect of logging on rodent scatter-hoarding dynamics in tropical forests: Implications for plant recruitment. Integrative Zoology 6(2): 74-80. DOI: https://doi.org/10.1111/j.1749-4877.2011.00234.x

Hampe, A., J. L. García-Castaño, E. H. Shupp and P. Jordano. 2008. Spatiotemporal dynamics and local hotspots of initial recruitment in vertebrate-dispersed trees. Journal of Ecology 96(4): 668-678. DOI: https://doi.org/10.1111/j.13652745.2008.01364.x

Harms, K. E., S. J. Wright, O. Calderón, O., A. Hernández and E. A. Herre. 2000. Pervasive density dependent recruitment enhances seedling diversity in a tropical forest. Nature 404: 493-495. DOI: https://doi.org/10.1038/35006630

Harrison, S. and E. Bruna. 1998. Habitat fragmentation and large-scale conservation: What do we know for sure? Ecography 22(3): 225-272. DOI: https://doi. org/10.1111/j.1600-0587.1999.tb00496.x

Hernández-Xolocotzi, E. 1993. Utilización de los recursos vegetales de México. In: Moreno-Casasola, P. and Rzedowski, J. (eds.). Logros y perspectivas del conocimiento de los recursos vegetales de México en visperas del siglo XXI. Instituto de Ecología, A.C. Xalapa, México. Pp. 57-62.

Herrera, J. M. and D. García. 2010. Effects of forest fragmentation on seed dispersal and seedling establishment in ornithochorous trees. Conservation Biology 24(4): 1089-1098. DOI: https://doi.org/10.1111/j.1523-1739.2010.01459.x

Heywood, V. H. and J. M. Iriondo. 2003. Plant conservation: Old problems, new perspectives. Biological Conservation 113(3): 321335. DOI: https://doi.org/10.1016/s0006-3207(03)00121-6

Howe, H. F. and M. N. Miriti. 2004. When seed dispersal matters. BioScience 54(7): 651-660. DOI: https://doi.org/10.1641/0 006-3568(2004)054[0651:WSDM]2.0.CO;2

Huston, M. A. 1994. Biological Diversity: The coexistence of species on changing landscapes. Cambridge University Press. New York, USA. 681 pp.

INE. 2000. Programa de manejo de la Reserva de la Biosfera Montes Azules. Instituto Nacional de Ecología. Secretaría de Medio Ambiente y Recursos Naturales. Cd. Mx., México.

Janzen, D. H. 1973. Tropical agroecosystems. Science 182(4118):12121219. DOI: https://doi.org/10.1016/0304-3746(78)90023-9

Janzen, D. H. 1983. No park is an island: increasing in interference from outside as park size decreases. Oikos 41: 402-410. DOI: https://doi.org/10.2307/3544100
Janzen, D. H. 1986. The future of tropical ecology. Annual Review Ecology Systematics 17: 305-324. DOI: https://doi. org/10.1146/annurev.es.17.110186.001513

Kellman, M., R. Tackaberry and L. Rigg. 1998. Structure and function in two tropical gallery forest communities: implications for forest conservation in fragmented systems. Journal of Applied Ecology 35(2): 195-2006. DOI: https://doi. org/10.1046/j.1365-2664.1998.00300.x

Krupnick, G. A. 2013. Conservation of tropical plant biodiversity: What have we done, where are we going? Biotropica 45(6): 693-708. DOI: https://doi.org/10.1111/btp.12064

Laurance, W. F., J. Sayer and K. G. Cassman. 2014. Agricultural expansion and its impacts on tropical nature. Trends in Ecology and Evolution 29: 107-116. DOI: https://doi.org/10.1016/j. tree.2013.12.001

Levey, D. J., B. M. Bolker, J. J. Tewksbury, S. Sargent and N. M. Haddad. 2005. Effects of landscape corridors on seed dispersal by birds. Science 309(5731): 146-148. DOI: https:// doi.org/10.1126/science.1111479

Levy-Tacher, S. I., J. R. Aguirre-Rivera, M. M. Martínez-Rivero and A. Durán-Fernández. 2002. Caracterización del uso tradicional de la flora espontánea en la comunidad lacandona de Lacanhá, Chiapas, México. Interciencia 27: 512-520.

Levy-Tacher, S., N. Ramírez-Marcial, M. González-Espinosa and F. Román-Dañobeytia. 2012. Rehabilitación ecológica de áreas agropecuarias degradadas en la Selva Lacandona: una alternativa fincada en el conocimiento ecológico tradicional maya. In: Bello Baltazar, E., E. J. Naranjo Piñera and R. Vandame (eds.). La otra innovación para el ambiente y la sociedad en la frontera sur de México. El Colegio de la Frontera Sur. San Cristóbal de Las Casas, Chiapas, México. Pp. 248-258.

Lindenmayer, D. B. y J. Fischer. 2006. Habitat fragmentation and landscape change. An ecological and conservation synthesis. Island Press, Washington, D.C., USA. 352 pp.

Lindenmayer, D. B. y J. Fischer. 2007. Tackling the habitat fragmentation panchreston. Trends in Ecology and Evolution 22(3): 127-132. DOI: https://doi.org/10.1016/j.tree.2006.11.006

Lôbo, D., T. Leâo, F. P. L. Melo, A. M. M. Santos y M. Tabarelli. 2011. Forest fragmentation drives Atlantic forest of northeastern Brazil to biotic homogenization. Diversity and Distribution 17(2): 287-296. DOI: https://doi.org/10.1111/ j.1472-4642.2010.00739.x 
López-Toledo, L. and M. Martínez-Ramos. 2011. The soil seed bank in abandoned tropical pastures: source of regeneration or invasion? Revista Mexicana de Biodiversidad 82(2): 663-678. DOI: https://doi.org/10.22201/ib.20078706e.2011.2.462

Manly, B. F. J. 1991. Randomization and Monte Carlo methods in biology. Chapman and Hall. London, UK. 281 pp.

Medellín, R. A. 1994. Mammal diversity and conservation in the Selva Lacandona, Chiapas, Mexico. Conservation Biology 8(3): 780-799. DOI: https://doi.org/10.1046/j.15231739.1994.08030780.x

Medellín, R. A. and M. Equihua. 1998. Mammal species richness and habitat use in rainforest and abandoned agricultural fields in Chiapas, Mexico. Journal of Applied Ecology 35(1): 13-23. DOI: https://doi.org/10.1046/j.13652664.1998.00272.x

McEuen, A. B. and L. M. Curran. 2004. Seed dispersal and recruitment limitation across spatial scales in temperate forest fragments. Ecology 85(2): 507-518. DOI: https://doi. org/10.1890/03-4006

Nations, J. D. and R. B. Nigh. 1978. Cattle, cash, food and forest; the destruction of the American tropics and the Lacandon Maya Alternative. Culture and Agriculture 16(6): 1-6. DOI: https://doi.org/10.1525/cuag.1978.16.6.1

Nations, J. D. and R. B. Nigh. 1980. The evolutionary potential of Lacandon Maya sustained-yield tropical forest agriculture. Journal of Anthropology Research 36(1): 1-30. DOI: https:// doi.org/10.1086/jar.36.1.3629550

Nigh, R. 2008. Trees, fire and farmers: making woods and soil in the Maya forest. Journal of Ethnobiology 28(2): 231-243. https://doi.org/10.2993/0278-0771-28.2.231

Nigh, R. and A. W. S. Diemont. 2013. The Maya milpa: Fire and the legacy of living soil. Frontiers in Ecology and the Environment 11(Special Issue 1): e45-e54. DOI: https://doi. org/10.1890/120344

Ochoa-Gaona, S., F. Hernández-Vázquez, B. H. J. De Jong and F. D. Gurri-García. 2007. Pérdida de diversidad florística ante un gradiente de intensificación del sistema agrícola de roza tumba-quema: un estudio de caso en la selva lacandona, Chiapas, México. Boletín de la Sociedad Botánica de México 81: 65-80.

Ortega-Álvarez, R., A. Casas, F. Figueroa and L. A. Sánchez-González. 2019. Producir y conservar: nuevos horizontes en torno a los modelos de integración y separación territorial. Sociedad y Ambiente 18: 11-44.
Pennington, T. D. and J. Sarukhán. 2005. Árboles tropicales de México: manual para la identificación de las principales especies, Tercera edición. Universidad Nacional Autónoma de MéxicoFondo de Cultura Económica. México, D.F., México. 253 pp.

Potvin, C. and D. Roff. 1993. Distribution-free and robust statistical methods: Viable alternatives to parametric statistics. Ecology 74(6): 1617-1628. DOI: https://doi.org/10.2307/1939920

Quintana-Ascencio, P. F., M. González Espinosa, N. Ramírez Marcial, G. Domínguez-Vázquez and M. Martínez-Icó. 1996. Soil seed bank and regeneration of Tropical Rain Forest from milpa fields at The Selva Lacandona, Chiapas, Mexico. Biotropica 28(2): 192-209. DOI: https://doi.org/10.2307/2389074

R Core Team. 2013. R: A Language and Environment for Statistical Computing. R Foundation for Statistical Computing. Vienna, Austria. http://www.R-project.org

Reina, R. E. 1967. Milpas and milperos: Implications for prehistoric times. American Anthropology 69(1): 1-20. DOI: https://doi. org/10.1525/aa.1967.69.1.02a00020

Ricketts, T. H. 2001. The matrix matters: Effective isolation in fragmented landscapes. American Naturalist 158(1): 87-99. DOI: https://doi.org/10.1086/320863

Saulei, S. M. and M. D. Swaine. 1988. Rain forest seed dynamics during succession at Gogol, Papua New Guinea. Journal of Ecology 76: 1133-1152. DOI: https://doi. $\operatorname{org} / 10.2307 / 2260639$

Schupp, E. W. and M. Fuentes. 1995. Spatial patterns of seed dispersal and the unification of plant population ecology. EcoScience 2(3): 267-275. DOI: https://doi.org/10.1080/119568 60.1995 .11682293

Sheldon, K. S. and N. M. Nadkarni. 2013. Spatial and temporal variation of seed rain in the canopy and on the ground of a tropical cloud forest. Biotropica 45(5): 549-556. DOI: https://doi. org/10.1111/btp.12043

Sousa, T. R., Costa, F. R. C., Bentos, T. V., Leal Filho, N., Mesquita, R. C. G. and I. O. Ribeiro. 2017. The effect of forest fragmentation on the soil seed bank of Central Amazonia. Forest Ecology and Management 393: 105-112. DOI: https://doi. org/10.1016/j.foreco.2017.03.020

Tabarelli, M., A. V. Aguiar, L. C. Girão, C. A. Peres and A. V. Lopes. 2010. Effects of pioneer tree species hyperabundance on forest fragments in northeastern Brazil. Conservation Biology 24(6): 1654-1663. DOI: https://doi.org/10.1111/j.15231739.2010.01529.x 
Uhl, C. and K. Clark. 1983. Seed ecology of selected Amazon Basin successional species. Botanical Gazette 144(3): 419-425. DOI: https://doi.org/10.1086/337392

Uhl, C., K. Clark, H. Clark and P. Murphy. 1981. Early plant succession after cutting and burning in the upper Rio Negro region of the Amazon basin. Journal of Ecology 69: 631-649. DOI: https://doi.org/10.2307/2259689

Van Breugel, M., M. Martínez-Ramos and F. Bongers. 2006. Community dynamics during early secondary succession in Mexican tropical rain forests. Journal of Tropical Ecology 22(6): 663-674. DOI: https://doi.org/10.1017/ s0266467406003452

Vandermeer, J. and C. Carvajal. 2001. Metapopulation dynamics and the quality of the matrix. American Naturalist 158(3): 211-220. DOI: https://doi.org/10.1086/321318

Vieira, I. C. G., P. D. Toledo, J. D. Silva and H. Higuchi. 2008. Deforestation and threats to the biodiversity of Amazonia. Brazilian Journal of Biology 68(4): 949-956. DOI: https://dx.doi. org/10.1590/S1519-69842008000500004
Weerasinghe, M., M. S. Ashton, E. R. Hooper and B. M. P. Singhakumara. 2019. Floristics of soil seed banks on agricultural and disturbed land cleared of tropical forests. Restoration Ecology 27(1): 138-147. DOI: https://doi.org/10.1111/ rec.12711

Wearn, O. R., D. C. Reuman and R. M. Ewers. 2012. Extinction debt and windows of conservation opportunity in the Brazilian Amazon. Science 337(6091): 228-232. DOI: https://doi. org/10.1126/science.1219013

Wright, S. J. 2010. The future of tropical forests. Annals New York Academy of Sciences 1195(1): 1-27. DOI: https://doi. org/10.1111/j.1749-6632.2010.05455.x

Zang, R. G., W. Y. Zhang and Y. Ding. 2007. Seed dynamics in relation to gaps in a tropical montane rainforest of Hainan Island, South China: (I) Seed Rain. Journal of Integrative Plant Biology 49(11): 1565-1572. DOI: https://doi.org/10.1111/ j.1774-7909.2007.00577.x 
Appendix 1: Presence/absence of species collected as seeds in six successional conditions in the Selva Lacandona, Chiapas, Mexico (August 1990-July 1991). Lacanjá-Chansayab = l; Bonampak-Bethel = b; FV = life form: h: herb, I: vine, a: tree, s: shrub; SD = seed dispersal, Feshy fruits or grains: a = small seeds, $m$ = medium size seeds, $v$ = large seeds, $d$ = unknown fruit type; Successional conditions: Mature forests = sma; Mid-successional forests = smm; Center of milpa field within forests = mcb; Border of milpa fields within forests = mbb; Early successional forests (fallows) = aca; Milpas within disturbed areas $=$ mil; grasslands $=$ pas. ${ }^{*}$ exotic.

\begin{tabular}{|c|c|c|c|c|c|c|c|c|c|c|c|c|c|c|c|c|}
\hline Family / Species & FV & SD & Isma & bsma & Ismm & bsmm & Imcb & Imbb & bmcb & bmbb & laca & baca & Imil & bmil & Ipas & bpas \\
\hline \multicolumn{17}{|l|}{ Acanthaceae } \\
\hline Mendoncia retusa Turril & $\mathrm{h}$ & $\mathrm{m}$ & 0 & 1 & 1 & 1 & 0 & 1 & 0 & 1 & 0 & 0 & 0 & 0 & 0 & 0 \\
\hline \multicolumn{17}{|l|}{ Actinidiaceae } \\
\hline Saurauia scabrida Hemsl. & $a$ & a & 0 & 0 & 0 & 0 & 0 & 0 & 0 & 0 & 1 & 1 & 0 & 0 & 0 & 0 \\
\hline \multicolumn{17}{|l|}{ Amaranthaceae } \\
\hline $\begin{array}{l}\text { Chamissoa altissima (Jacq.) } \\
\text { Kunth }\end{array}$ & 1 & a & 0 & 0 & 1 & 1 & 0 & 0 & 0 & 0 & 0 & 0 & 0 & 0 & 0 & 0 \\
\hline Iresine spp. & $\mathrm{h}$ & a & 1 & 0 & 0 & 0 & 1 & 1 & 1 & 1 & 0 & 1 & 1 & 1 & 1 & 1 \\
\hline \multicolumn{17}{|l|}{ Anacardiaceae } \\
\hline Spondias mombin L. & $a$ & $v$ & 1 & 1 & 1 & 1 & 0 & 1 & 0 & 0 & 0 & 0 & 0 & 0 & 0 & 0 \\
\hline \multicolumn{17}{|l|}{ Annonaceae } \\
\hline Annona mucosa Jacq. & a & $\mathrm{m}$ & 0 & 1 & 1 & 0 & 0 & 0 & 0 & 0 & 0 & 0 & 0 & 0 & 0 & 0 \\
\hline $\begin{array}{l}\text { Cymbopetalum bailonii R.E. } \\
\text { Fr. }\end{array}$ & $a$ & $\mathrm{~m}$ & 0 & 1 & 1 & 0 & 0 & 0 & 0 & 0 & 0 & 0 & 0 & 0 & 0 & 0 \\
\hline \multicolumn{17}{|l|}{ Apocynaceae } \\
\hline Asclepias spp. & 1 & $\mathrm{~m}$ & 0 & 1 & 0 & 0 & 1 & 1 & 0 & 0 & 0 & 0 & 0 & 0 & 0 & 0 \\
\hline $\begin{array}{l}\text { Forsteronia myriantha Donn. } \\
\text { Sm. }\end{array}$ & 1 & $\mathrm{~m}$ & 1 & 1 & 1 & 1 & 1 & 1 & 0 & 1 & 0 & 0 & 0 & 0 & 0 & 0 \\
\hline $\begin{array}{l}\text { Tabernaemontana donnell- } \\
\text { smithii Rose }\end{array}$ & $a$ & $\mathrm{~m}$ & 1 & 1 & 1 & 0 & 0 & 1 & 0 & 0 & 0 & 1 & 0 & 0 & 0 & 0 \\
\hline \multicolumn{17}{|l|}{ Araceae } \\
\hline sp. 1 & $\mathrm{~h}$ & $v$ & 0 & 1 & 1 & 1 & 0 & 0 & 0 & 0 & 0 & 0 & 0 & 0 & 0 & 0 \\
\hline \multicolumn{17}{|l|}{ Araliaceae } \\
\hline $\begin{array}{l}\text { Dendropanax arboreus (L.) } \\
\text { Decne. \& Planch. }\end{array}$ & $a$ & $\mathrm{~m}$ & 1 & 0 & 0 & 1 & 0 & 0 & 0 & 0 & 0 & 0 & 0 & 0 & 0 & 0 \\
\hline $\begin{array}{l}\text { Oreopanax guatemalensis } \\
\text { (Lem. ex Bosse) Decne. \& } \\
\text { Planch. }\end{array}$ & $a$ & $\mathrm{~m}$ & 0 & 0 & 1 & 1 & 0 & 0 & 0 & 0 & 0 & 1 & 0 & 0 & 0 & 0 \\
\hline sp. 2 & $\mathrm{~h}$ & $d$ & 1 & 1 & 1 & 1 & 0 & 0 & 0 & 1 & 0 & 1 & 0 & 0 & 0 & 0 \\
\hline \multicolumn{17}{|l|}{ Arecaceae } \\
\hline Chamaedorea spp. & s & $\mathrm{m}$ & 1 & 1 & 1 & 1 & 0 & 1 & 0 & 0 & 0 & 0 & 0 & 0 & 0 & 0 \\
\hline \multicolumn{17}{|l|}{ Asteraceae } \\
\hline Bidens spp. & $\mathrm{h}$ & a & 0 & 0 & 0 & 0 & 0 & 1 & 0 & 0 & 0 & 0 & 1 & 1 & 0 & 0 \\
\hline $\begin{array}{l}\text { Clibadium arboreum Donn. } \\
\text { Sm. }\end{array}$ & $\mathrm{s}$ & a & 0 & 0 & 0 & 0 & 0 & 0 & 0 & 0 & 1 & 1 & 0 & 0 & 0 & 0 \\
\hline Asteraceae & $\mathrm{h}$ & a & 1 & 1 & 1 & 1 & 1 & 1 & 1 & 1 & 1 & 1 & 1 & 1 & 1 & 1 \\
\hline $\begin{array}{l}\text { Erechtites hieraciifolius (L.) } \\
\text { Raf. ex DC. }\end{array}$ & $\mathrm{h}$ & a & 0 & 0 & 0 & 0 & 0 & 0 & 0 & 0 & 0 & 0 & 0 & 0 & 1 & 0 \\
\hline Zexmenia spp. & $\mathrm{h}$ & a & 0 & 0 & 0 & 0 & 0 & 0 & 0 & 0 & 0 & 1 & 0 & 1 & 0 & 0 \\
\hline \multicolumn{17}{|l|}{ Bignoniaceae } \\
\hline $\begin{array}{l}\text { Fridericia schumanniana } \\
\text { (Loes.) L.G. Lohmann }\end{array}$ & 1 & $\mathrm{~m}$ & 1 & 1 & 0 & 0 & 0 & 0 & 0 & 0 & 0 & 0 & 0 & 0 & 0 & 0 \\
\hline $\begin{array}{l}\text { Tanaecium pyramidatum } \\
\text { (Rich.) L.G. Lohmann }\end{array}$ & I & $v$ & 1 & 0 & 1 & 1 & 0 & 0 & 0 & 1 & 0 & 0 & 0 & 0 & 0 & 0 \\
\hline
\end{tabular}


Appendix 1: Continuation.

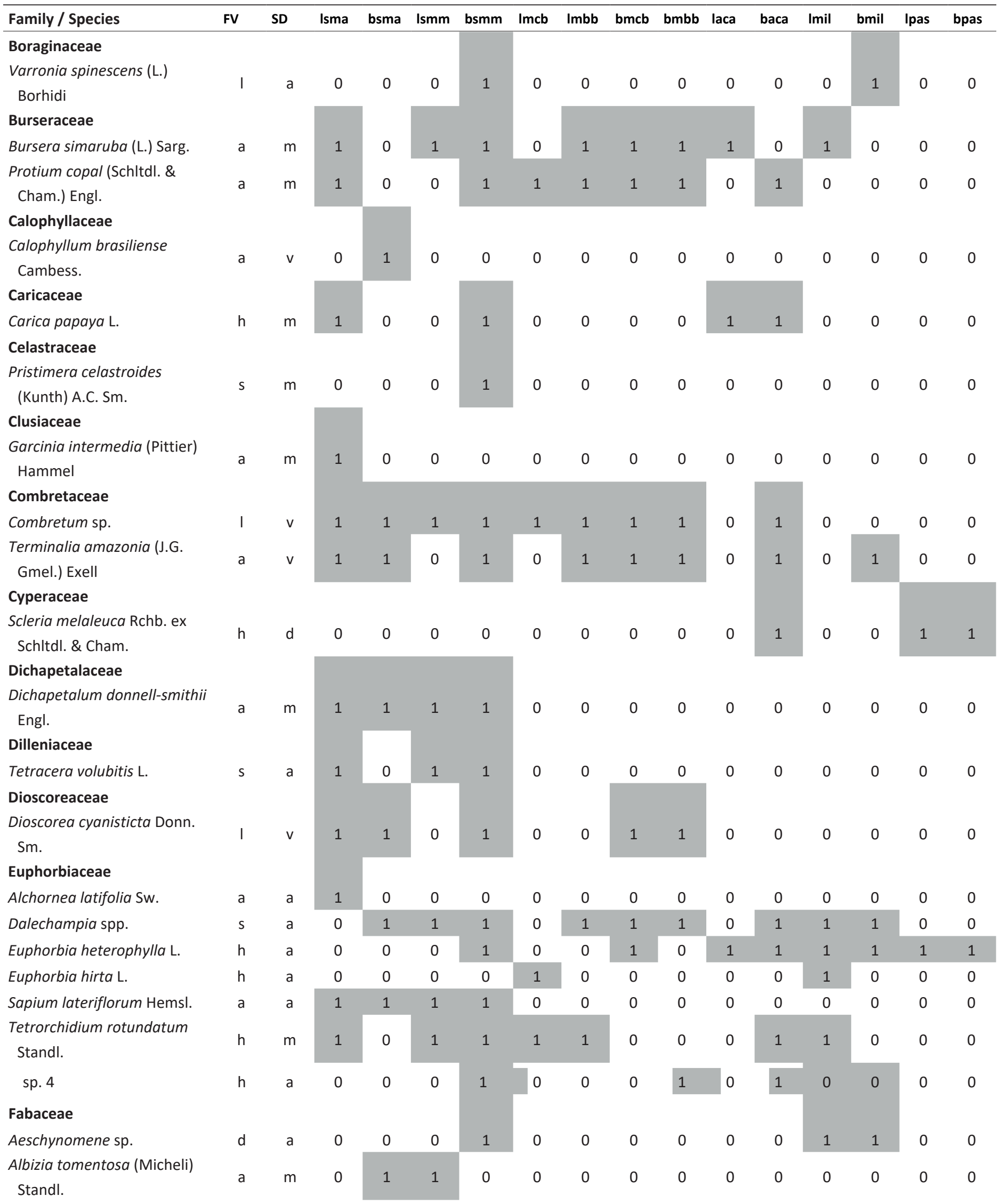


Appendix 1: Continuation.

\begin{tabular}{|c|c|c|c|c|c|c|c|c|c|c|c|c|c|c|c|c|}
\hline Family / Species & FV & SD & Isma & bsma & Ismm & bsmm & Imcb & Imbb & bmcb & bmbb & laca & baca & Imil & bmil & Ipas & bpas \\
\hline $\begin{array}{l}\text { Cojoba arborea (L.) Britton } \\
\text { \& Rose }\end{array}$ & a & $\mathrm{m}$ & 0 & 1 & 0 & 1 & 0 & 0 & 0 & 0 & 0 & 0 & 0 & 0 & 0 & 0 \\
\hline Crotalaria spectabilis Roth & a & a & 0 & 0 & 1 & 0 & 0 & 0 & 0 & 0 & 0 & 0 & 1 & 0 & 0 & 0 \\
\hline Dalbergia glomerata Hemsl. & $d$ & $\mathrm{~m}$ & 1 & 1 & 1 & 1 & 0 & 0 & 0 & 1 & 0 & 0 & 0 & 0 & 0 & 0 \\
\hline Desmodium spp. & $\mathrm{h}$ & a & 0 & 0 & 0 & 0 & 0 & 0 & 0 & 0 & 0 & 0 & 1 & 1 & 0 & 0 \\
\hline $\begin{array}{l}\text { Dialum guianense (Aubl.) } \\
\text { Sandwith }\end{array}$ & a & $\mathrm{m}$ & 0 & 1 & 1 & 1 & 1 & 0 & 1 & 1 & 0 & 0 & 0 & 0 & 0 & 0 \\
\hline Lonchocarpus spp. & a & $\mathrm{m}$ & 0 & 0 & 0 & 0 & 0 & 0 & 0 & 0 & 0 & 1 & 0 & 0 & 0 & 0 \\
\hline $\begin{array}{l}\text { Machaerium floribundum } \\
\text { Benth. }\end{array}$ & 1 & $v$ & 1 & 1 & 0 & 1 & 0 & 0 & 0 & 0 & 0 & 0 & 0 & 0 & 0 & 0 \\
\hline Rhynchosia minima (L.) DC. & I & a & 1 & 1 & 1 & 1 & 0 & 0 & 0 & 0 & 0 & 0 & 0 & 0 & 0 & 0 \\
\hline $\begin{array}{l}\text { Schizolobium parahyba (Vell.) } \\
\text { S.F. Blake }\end{array}$ & a & v & 0 & 0 & 1 & 0 & 0 & 0 & 0 & 0 & 0 & 0 & 0 & 0 & 0 & 0 \\
\hline sp. 7 & $d$ & $d$ & 0 & 1 & 0 & 1 & 0 & 0 & 0 & 0 & 0 & 0 & 0 & 0 & 0 & 0 \\
\hline sp. 8 & $d$ & v & 0 & 1 & 0 & 0 & 0 & 0 & 0 & 0 & 0 & 1 & 0 & 0 & 0 & 0 \\
\hline sp. 9 & $d$ & $a$ & 1 & 1 & 0 & 1 & 0 & 0 & 0 & 0 & 0 & 0 & 0 & 0 & 0 & 0 \\
\hline Gesneriaceae & & & & & & & & & & & & & & & & \\
\hline sp. 5 & $d$ & $d$ & 1 & 1 & 1 & 0 & 1 & 1 & 0 & 0 & 0 & 0 & 0 & 0 & 0 & 0 \\
\hline Hernandiaceae & & & & & & & & & & & & & & & & \\
\hline $\begin{array}{l}\text { Sparattanthelium amazonum } \\
\text { Mart. }\end{array}$ & $d$ & $\mathrm{~m}$ & 1 & 0 & 1 & 1 & 0 & 0 & 0 & 0 & 0 & 0 & 0 & 0 & 0 & 0 \\
\hline Lauraceae & & & & & & & & & & & & & & & & \\
\hline sp. 6 & $a$ & $a$ & 0 & 0 & 1 & 0 & 0 & 0 & 0 & 0 & 0 & 0 & 0 & 0 & 0 & 0 \\
\hline Malpighiaceae & & & & & & & & & & & & & & & & \\
\hline $\begin{array}{l}\text { Heteropterys laurifolia (L.) A. } \\
\text { Juss. }\end{array}$ & $\mathrm{s}$ & $v$ & 1 & 0 & 1 & 1 & 0 & 0 & 0 & 0 & 0 & 0 & 1 & 0 & 0 & 0 \\
\hline Psychopterys rivularis (C.V. & & & & & & & & & & & & & & & & \\
\hline $\begin{array}{l}\text { Morton \& Standl.) W.R. } \\
\text { Anderson \& S. Corso }\end{array}$ & I & $v$ & 0 & 1 & 0 & 0 & 0 & 0 & 0 & 0 & 0 & 0 & 0 & 0 & 0 & 0 \\
\hline Mascagnia vaccinifolia Nied. & 1 & $v$ & 0 & 1 & 1 & 1 & 0 & 0 & 1 & 1 & 0 & 0 & 0 & 1 & 0 & 0 \\
\hline $\begin{array}{l}\text { Tetrapteris glabrifolia } \\
\text { (Griseb.) Small }\end{array}$ & 1 & $v$ & 1 & 0 & 0 & 1 & 0 & 0 & 0 & 0 & 0 & 0 & 0 & 0 & 0 & 0 \\
\hline Malvaceae & & & & & & & & & & & & & & & & \\
\hline Hampea mexicana Fryxell & a & $\mathrm{m}$ & 0 & 0 & 1 & 0 & 0 & 0 & 0 & 0 & 0 & 0 & 0 & 0 & 0 & 0 \\
\hline Heliocarpus spp. & a & $v$ & 1 & 1 & 1 & 0 & 1 & 1 & 0 & 0 & 0 & 1 & 1 & 1 & 0 & 0 \\
\hline Quararibea spp. & a & $v$ & 1 & 1 & 1 & 1 & 0 & 1 & 0 & 0 & 0 & 1 & 0 & 0 & 0 & 0 \\
\hline Sida rhombifolia L. & $\mathrm{h}$ & a & 1 & 0 & 0 & 0 & 0 & 0 & 0 & 0 & 0 & 0 & 0 & 1 & 0 & 0 \\
\hline $\begin{array}{l}\text { Trichospermum galeottii } \\
\text { (Turcz.) Kosterm. }\end{array}$ & a & $v$ & 0 & 0 & 0 & 0 & 0 & 0 & 0 & 1 & 0 & 1 & 0 & 0 & 0 & 0 \\
\hline Marcgraviaceae & & & & & & & & & & & & & & & & \\
\hline sp. 10 & $d$ & $\mathrm{a}$ & 1 & 1 & 1 & 0 & 1 & 1 & 0 & 0 & 0 & 0 & 0 & 0 & 0 & 0 \\
\hline sp. 11 & $d$ & a & 1 & 1 & 1 & 0 & 1 & 0 & 0 & 0 & 0 & 0 & 0 & 0 & 0 & 0 \\
\hline Melastomataceae & & & & & & & & & & & & & & & & \\
\hline Miconia argentea (Sw.) DC. & a & $\mathrm{m}$ & 1 & 1 & 1 & 1 & 0 & 0 & 0 & 0 & 0 & 0 & 0 & 0 & 0 & 0 \\
\hline Meliaceae & & & & & & & & & & & & & & & & \\
\hline Guarea glabra Vahl & a & $\mathrm{m}$ & 0 & 0 & 1 & 1 & 0 & 0 & 0 & 0 & 0 & 0 & 0 & 0 & 0 & 0 \\
\hline Guarea sp. & a & a & 0 & 1 & 0 & 0 & 0 & 0 & 0 & 0 & 0 & 0 & 0 & 0 & 0 & 0 \\
\hline
\end{tabular}


Appendix 1: Continuation.

\begin{tabular}{|c|c|c|c|c|c|c|c|c|c|c|c|c|c|c|c|c|}
\hline Family / Species & FV & SD & Isma & bsma & Ismm & bsmm & Imcb & Imbb & bmcb & bmbb & laca & baca & Imil & bmil & Ipas & bpas \\
\hline Swietenia macrophylla G. King & a & $v$ & 0 & 1 & 0 & 0 & 0 & 0 & 0 & 0 & 0 & 1 & 0 & 0 & 0 & 0 \\
\hline Trichilia pallida Sw. & a & $\mathrm{m}$ & 1 & 0 & 0 & 0 & 0 & 0 & 0 & 0 & 0 & 0 & 0 & 0 & 0 & 0 \\
\hline \multicolumn{17}{|l|}{ Monimiaceae } \\
\hline Mollinedia viridiflora Tul. & s & a & 0 & 0 & 0 & 0 & 0 & 0 & 0 & 0 & 0 & 0 & 1 & 0 & 0 & 0 \\
\hline \multicolumn{17}{|l|}{ Moraceae } \\
\hline Brosimum alicastrum Sw. & a & $\mathrm{m}$ & 1 & 1 & 1 & 1 & 0 & 0 & 0 & 1 & 0 & 0 & 0 & 0 & 0 & 0 \\
\hline Brosimum sp. & a & $\mathrm{m}$ & 0 & 0 & 1 & 0 & 0 & 0 & 0 & 0 & 0 & 0 & 0 & 0 & 0 & 0 \\
\hline Cecropia spp. & a & a & 1 & 1 & 1 & 1 & 1 & 1 & 1 & 1 & 1 & 1 & 1 & 1 & 0 & 0 \\
\hline Ficus aurea Nutt. & a & a & 1 & 1 & 1 & 1 & 1 & 1 & 1 & 1 & 0 & 1 & 1 & 1 & 1 & 0 \\
\hline Ficus insipida Willd. & a & $\mathrm{a}$ & 1 & 1 & 1 & 1 & 1 & 1 & 0 & 1 & 1 & 1 & 0 & 0 & 0 & 0 \\
\hline Ficus jimenezii Standl. & a & $\mathrm{a}$ & 1 & 1 & 1 & 1 & 0 & 0 & 1 & 0 & 0 & 0 & 0 & 0 & 0 & 0 \\
\hline Ficus obtusifolia Kunth & a & a & 0 & 0 & 0 & 1 & 1 & 1 & 1 & 0 & 0 & 0 & 0 & 0 & 0 & 0 \\
\hline Pseudolmedia sp. & a & a & 0 & 0 & 1 & 1 & 0 & 1 & 0 & 1 & 0 & 0 & 0 & 0 & 0 & 0 \\
\hline \multicolumn{17}{|l|}{ Muntingiaceae } \\
\hline Muntingia calabura L. & a & a & 0 & 0 & 0 & 0 & 0 & 0 & 0 & 0 & 1 & 0 & 0 & 0 & 0 & 0 \\
\hline \multicolumn{17}{|l|}{ Orchidaceae } \\
\hline sp. 12 & $\mathrm{~h}$ & $v$ & 0 & 1 & 1 & 1 & 0 & 0 & 0 & 0 & 0 & 0 & 0 & 0 & 0 & 0 \\
\hline
\end{tabular}

\section{Phytolacaceae}

Phytolacca rivinoides Kunth \& C.D. Bouché

Thrichostigma octandrum (L.)

H. Walter

\section{Piperaceae}

Piper amalago L.

Piper sp.1

Piper sp. 2

Poaceae

Andropogon bicornis $\mathrm{L}$.

Hyparrhenia rufa* (Nees)

Stapf

Lasciasis nigra Davidse

Paspalum conjugatum P.J.

Bergius

Paspalum paniculatum L. Paspalum virgatum $\mathrm{L}$.

Ranunculaceae

Clematis dioica $\mathrm{L}$.

Clematis haenkeana C. Presl.

Rhamnaceae

Goguania lupuloides (L.) Urb.

Rubiaceae

Manettia reclinata Mutis ex $\mathrm{L}$. Palicourea tetragona (Donn.

Sm.) C.M. Taylor \& Lorence

Psychotria limonensis $\mathrm{K}$.

Krause

Psychotria pubescens Sw.

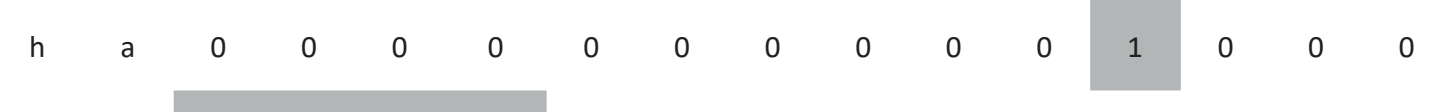


Appendix 1: Continuation.

\begin{tabular}{|c|c|c|c|c|c|c|c|c|c|c|c|c|c|c|c|c|}
\hline Family / Species & FV & SD & Isma & bsma & Ismm & bsmm & Imcb & Imbb & bmcb & bmbb & laca & baca & Imil & bmil & Ipas & bpas \\
\hline $\begin{array}{l}\text { Rudgea cornifolia (Kunth) } \\
\text { Standl. }\end{array}$ & $\mathrm{s}$ & $\mathrm{m}$ & 1 & 1 & 1 & 1 & 0 & 0 & 0 & 1 & 0 & 0 & 0 & 0 & 0 & 0 \\
\hline \multicolumn{17}{|l|}{ Sapindaceae } \\
\hline Paullinia tomentosa Jacq. & 1 & $\mathrm{~m}$ & 1 & 0 & 0 & 0 & 0 & 1 & 0 & 1 & 1 & 0 & 0 & 0 & 0 & 0 \\
\hline Serjania goniocarpa Radlk. & 1 & $v$ & 1 & 1 & 1 & 1 & 0 & 1 & 0 & 1 & 0 & 1 & 1 & 0 & 0 & 0 \\
\hline \multicolumn{17}{|l|}{ Sapotaceae } \\
\hline sp. 14 & a & $\mathrm{m}$ & 1 & 0 & 1 & 1 & 0 & 0 & 0 & 0 & 0 & 0 & 0 & 0 & 0 & 0 \\
\hline \multicolumn{17}{|l|}{ Solanaceae } \\
\hline Cestrum spp. & s & a & 1 & 1 & 1 & 1 & 0 & 0 & 0 & 0 & 0 & 1 & 1 & 0 & 0 & 0 \\
\hline $\begin{array}{l}\text { Lycianthes heteroclita } \\
\text { (Sendtn.) Bitter }\end{array}$ & $\mathrm{s}$ & $\mathrm{a}$ & 1 & 0 & 0 & 0 & 1 & 0 & 0 & 0 & 0 & 0 & 0 & 0 & 0 & 0 \\
\hline Lycianthes spp. & 1 & a & 0 & 0 & 0 & 0 & 1 & 1 & 1 & 1 & 0 & 0 & 0 & 0 & 0 & 0 \\
\hline Solanum americanum Mill. & s & a & 0 & 0 & 0 & 0 & 1 & 0 & 0 & 0 & 0 & 0 & 0 & 0 & 0 & 0 \\
\hline Solanum hispidum Pers. & s & a & 0 & 0 & 1 & 1 & 1 & 1 & 1 & 1 & 1 & 1 & 1 & 1 & 0 & 0 \\
\hline \multicolumn{17}{|l|}{ Urticaceae } \\
\hline Boehmeria ulmifolia Wedd. & $\mathrm{h}$ & $\mathrm{a}$ & 0 & 0 & 1 & 0 & 0 & 0 & 0 & 0 & 1 & 1 & 0 & 0 & 0 & 0 \\
\hline \multicolumn{17}{|l|}{ Violaceae } \\
\hline Rinorea spp. & s & a & 1 & 1 & 1 & 1 & 1 & 1 & 1 & 1 & 0 & 1 & 0 & 0 & 0 & 0 \\
\hline \multicolumn{17}{|l|}{ Undetermined } \\
\hline sp. 15 & $d$ & $a$ & 0 & 0 & 0 & 1 & 0 & 0 & 0 & 0 & 0 & 0 & 0 & 0 & 0 & 0 \\
\hline sp. 16 & $d$ & $a$ & 0 & 0 & 0 & 0 & 0 & 0 & 0 & 0 & 0 & 0 & 0 & 1 & 1 & 0 \\
\hline sp. 17 & $d$ & $a$ & 0 & 0 & 0 & 0 & 0 & 1 & 0 & 0 & 0 & 0 & 0 & 0 & 0 & 0 \\
\hline sp. 18 & $d$ & $d$ & 0 & 0 & 1 & 0 & 0 & 0 & 1 & 0 & 0 & 0 & 0 & 0 & 0 & 0 \\
\hline sp. 19 & $d$ & $v$ & 0 & 0 & 1 & 1 & 0 & 0 & 0 & 0 & 0 & 0 & 0 & 0 & 0 & 0 \\
\hline sp. 20 & $d$ & $\mathrm{~m}$ & 0 & 1 & 0 & 0 & 0 & 0 & 0 & 0 & 0 & 0 & 0 & 0 & 0 & 0 \\
\hline sp. 21 & $d$ & $\mathrm{~m}$ & 1 & 0 & 0 & 0 & 0 & 0 & 0 & 0 & 0 & 0 & 0 & 0 & 0 & 0 \\
\hline sp. 22 & $d$ & $\mathrm{~m}$ & 0 & 0 & 1 & 0 & 0 & 0 & 1 & 0 & 0 & 0 & 0 & 0 & 0 & 0 \\
\hline sp. 23 & $d$ & $a$ & 0 & 0 & 1 & 1 & 0 & 0 & 0 & 0 & 0 & 0 & 0 & 0 & 0 & 0 \\
\hline sp. 24 & $d$ & $a$ & 0 & 0 & 0 & 1 & 0 & 0 & 0 & 0 & 0 & 0 & 0 & 0 & 0 & 0 \\
\hline sp. 25 & $d$ & $a$ & 0 & 0 & 1 & 1 & 0 & 0 & 0 & 0 & 0 & 0 & 1 & 0 & 0 & 0 \\
\hline sp. 26 & $d$ & $a$ & 0 & 0 & 0 & 1 & 0 & 1 & 0 & 0 & 0 & 0 & 0 & 0 & 0 & 0 \\
\hline sp. 27 & $d$ & $a$ & 0 & 0 & 1 & 1 & 0 & 0 & 0 & 0 & 0 & 0 & 0 & 0 & 0 & 0 \\
\hline sp. 28 & $d$ & $m$ & 1 & 1 & 0 & 0 & 0 & 0 & 0 & 0 & 0 & 0 & 0 & 0 & 0 & 0 \\
\hline sp. 29 & $d$ & $m$ & 0 & 1 & 0 & 0 & 0 & 0 & 0 & 0 & 0 & 0 & 0 & 0 & 0 & 0 \\
\hline sp. 30 & $d$ & $a$ & 0 & 0 & 0 & 0 & 0 & 0 & 0 & 0 & 0 & 1 & 0 & 0 & 0 & 0 \\
\hline sp. 31 & $d$ & $a$ & 0 & 0 & 1 & 1 & 0 & 0 & 0 & 0 & 0 & 0 & 1 & 1 & 0 & 0 \\
\hline sp. 32 & $d$ & $a$ & 0 & 0 & 0 & 0 & 0 & 0 & 1 & 1 & 0 & 0 & 0 & 0 & 0 & 0 \\
\hline sp. 33 & $d$ & $a$ & 0 & 0 & 0 & 0 & 0 & 0 & 0 & 0 & 0 & 1 & 0 & 0 & 0 & 0 \\
\hline sp. 34 & $d$ & v & 1 & 1 & 1 & 1 & 0 & 0 & 0 & 0 & 0 & 0 & 0 & 0 & 0 & 0 \\
\hline sp. 35 & $d$ & $a$ & 1 & 1 & 1 & 1 & 0 & 0 & 1 & 0 & 0 & 0 & 0 & 0 & 0 & 0 \\
\hline sp. 36 & $d$ & $a$ & 0 & 0 & 1 & 1 & 0 & 0 & 0 & 0 & 0 & 0 & 0 & 0 & 0 & 0 \\
\hline sp. 37 & $d$ & $a$ & 0 & 0 & 0 & 0 & 0 & 0 & 1 & 1 & 0 & 1 & 1 & 0 & 0 & 0 \\
\hline sp. 38 & $d$ & $a$ & 1 & 1 & 1 & 1 & 0 & 0 & 1 & 1 & 0 & 0 & 0 & 0 & 0 & 0 \\
\hline sp. 39 & $d$ & $m$ & 0 & 0 & 0 & 0 & 0 & 0 & 0 & 0 & 0 & 0 & 1 & 0 & 0 & 0 \\
\hline sp. 40 & $d$ & $\mathrm{~m}$ & 0 & 0 & 1 & 0 & 0 & 0 & 0 & 1 & 0 & 0 & 0 & 0 & 0 & 0 \\
\hline sp. 41 & $d$ & $\mathrm{a}$ & 0 & 0 & 0 & 0 & 0 & 0 & 0 & 0 & 0 & 1 & 0 & 0 & 0 & 0 \\
\hline
\end{tabular}


Appendix 1: Continuation.

\begin{tabular}{|c|c|c|c|c|c|c|c|c|c|c|c|c|c|c|c|c|}
\hline Family / Species & FV & SD & Isma & bsma & Ismm & bsmm & Imcb & Imbb & bmcb & bmbb & laca & baca & Imil & bmil & Ipas & bpas \\
\hline sp. 42 & $d$ & $\mathrm{~m}$ & 0 & 0 & 0 & 1 & 0 & 0 & 0 & 0 & 0 & 1 & 0 & 0 & 0 & 0 \\
\hline sp. 43 & $d$ & v & 1 & 0 & 0 & 0 & 0 & 0 & 0 & 0 & 0 & 0 & 0 & 0 & 0 & 0 \\
\hline Total & & & 60 & 61 & 70 & 72 & 25 & 34 & 26 & 35 & 17 & 44 & 31 & 26 & 14 & 11 \\
\hline
\end{tabular}


Appendix 2: Presence/absence of species found as seedlings in three forested successional communities in the Selva Lacandona, Chiapas, Mexico (August 1990-July 1991). Lacanjá-Chansayab = I; Bonampak-Bethel= b; Successional communities: Mature forests = sma; Mid-successional forests = smm; Early-successional forests (fallows) = aca.

\begin{tabular}{|c|c|c|c|c|c|c|c|c|}
\hline Id & Family & Species & Isma & bsma & Ismm & bsmm & laca & baca \\
\hline sp. 1 & Rubiaceae & Psychotria mombachensis Standl. & 1 & 0 & 1 & 0 & 0 & 1 \\
\hline sp. 2 & & & 0 & 0 & 1 & 0 & 0 & 0 \\
\hline sp. 4 & Arecaceae & Chamaedorea spp. & 1 & 1 & 1 & 1 & 1 & 1 \\
\hline sp. 5 & & & 1 & 1 & 1 & 1 & 1 & 0 \\
\hline sp. 6 & & & 0 & 0 & 1 & 0 & 0 & 0 \\
\hline sp. 7 & Acanthaceae & Pseuderanthemum verapazense Donn. Sm. & 1 & 1 & 1 & 1 & 1 & 1 \\
\hline sp. 8 & Combretaceae & Combretum spp. & 1 & 1 & 1 & 1 & 0 & 0 \\
\hline sp. 11 & & & 1 & 1 & 1 & 1 & 0 & 0 \\
\hline sp. 12 & Moraceae & & 1 & 1 & 1 & 1 & 0 & 0 \\
\hline sp. 13 & Araceae & & 1 & 1 & 1 & 1 & 0 & 0 \\
\hline sp. 15 & & & 1 & 0 & 1 & 0 & 0 & 0 \\
\hline sp. 16 & Connaraceae & Connarus lentiginosus Brandegee & 1 & 0 & 1 & 0 & 0 & 0 \\
\hline sp. 18 & Moraceae & Poulsenia armata (Miq.) Standl. & 1 & 1 & 1 & 0 & 0 & 0 \\
\hline sp. 19 & Sapindaceae & Serjania goniocarpa Radlk. & 1 & 1 & 1 & 1 & 1 & 1 \\
\hline sp. 20 & Dryopteridaceae & Ctenitis excelsa (Desv.) Proctor & 1 & 0 & 1 & 0 & 0 & 0 \\
\hline sp. 24 & Fabaceae & & 1 & 1 & 1 & 0 & 0 & 1 \\
\hline sp. 27 & Musaceae & Heliconia sp. & 0 & 1 & 1 & 1 & 1 & 0 \\
\hline sp. 30 & Dioscoreaceae & Dioscorea sp. & 0 & 1 & 1 & 1 & 1 & 0 \\
\hline sp. 31 & & & 1 & 1 & 1 & 1 & 1 & 0 \\
\hline sp. 32 & Ulmaceae & Ampelocera hottlei (Standl.) Standl. & 0 & 1 & 1 & 1 & 0 & 0 \\
\hline sp. 34 & & & 1 & 1 & 1 & 0 & 0 & 0 \\
\hline sp. 35 & Sapindaceae & Paullinia costata Schltdl. \& Cham. & 1 & 1 & 1 & 1 & 0 & 0 \\
\hline sp. 36 & & & 1 & 0 & 1 & 1 & 0 & 0 \\
\hline sp. 37 & & & 0 & 0 & 0 & 1 & 0 & 0 \\
\hline sp. 38 & & & 0 & 1 & 1 & 1 & 0 & 0 \\
\hline sp. 39 & Piperaceae & Piper glabrescens (Miq.) C. DC. & 0 & 1 & 0 & 0 & 1 & 0 \\
\hline sp. 41 & & & 1 & 1 & 1 & 1 & 0 & 0 \\
\hline sp. 42 & & & 1 & 1 & 1 & 0 & 1 & 0 \\
\hline sp. 43 & Piperaceae & Piper psylorhachis C. DC. & 1 & 1 & 1 & 1 & 1 & 1 \\
\hline sp. 45 & Rubiaceae & Psychotria limonensis K. Krause & 0 & 0 & 1 & 1 & 0 & 0 \\
\hline sp. 46 & & & 1 & 1 & 1 & 1 & 0 & 1 \\
\hline sp. 49 & Rubiaceae & & 0 & 1 & 0 & 0 & 0 & 0 \\
\hline sp. 51 & & & 0 & 0 & 0 & 0 & 1 & 0 \\
\hline sp. 52 & Malvaceae & Hampea mexicana Fryxell & 1 & 1 & 1 & 1 & 0 & 0 \\
\hline sp. 54 & Clusiaceae & Garcinia intermedia (Pittier) Hammel & 0 & 1 & 1 & 0 & 0 & 0 \\
\hline sp. 55 & Burseraceae & Protium copal (Schltdl. \& Cham.) Engl. & 1 & 0 & 0 & 1 & 0 & 0 \\
\hline sp. 56 & Pteridaceae & Pteris altissima Poir. & 0 & 1 & 1 & 0 & 0 & 0 \\
\hline sp. 59 & & & 1 & 0 & 1 & 1 & 0 & 0 \\
\hline sp. 60 & & & 1 & 0 & 0 & 1 & 0 & 0 \\
\hline sp. 61 & & & 0 & 0 & 1 & 0 & 0 & 0 \\
\hline sp. 62 & Poaceae & Pharus parvifolius Nash & 0 & 1 & 0 & 1 & 0 & 0 \\
\hline
\end{tabular}


Appendix 2: Continuation.

\begin{tabular}{|c|c|c|c|c|c|c|c|c|}
\hline Id & Family & Species & Isma & bsma & Ismm & bsmm & laca & baca \\
\hline sp. 64 & Musaceae & Heliconia aurantiaca Ghiesbr. ex Lem. & 0 & 1 & 1 & 0 & 0 & 0 \\
\hline sp. 65 & Piperaceae & Piper grandilimbum C. DC. & 0 & 1 & 1 & 0 & 0 & 0 \\
\hline sp. 66 & & & 0 & 0 & 0 & 1 & 0 & 0 \\
\hline sp. 67 & & & 1 & 1 & 1 & 1 & 1 & 1 \\
\hline sp. 68 & & & 1 & 1 & 1 & 1 & 0 & 1 \\
\hline sp. 69 & Piperaceae & Piper uspantanense C. DC. & 0 & 1 & 0 & 0 & 1 & 1 \\
\hline sp. 70 & & & 1 & 0 & 0 & 0 & 0 & 0 \\
\hline sp. 71 & Arecaceae & Chamaedorea ernesti-augustii $\mathrm{H}$. Wendl. & 1 & 1 & 1 & 1 & 0 & 0 \\
\hline sp. 72 & Monimiaceae & Mollinedia sp. & 1 & 0 & 0 & 0 & 0 & 0 \\
\hline sp. 73 & Lauraceae & & 1 & 1 & 1 & 0 & 1 & 0 \\
\hline sp. 76 & Arecaceae & Bactris mexicana Liebm. ex Mart. & 1 & 0 & 0 & 1 & 0 & 0 \\
\hline sp. 77 & Araliaceae & Dendropanax arboreus (L.) Decne. \& Planch. & 1 & 1 & 1 & 1 & 1 & 1 \\
\hline sp. 78 & Moraceae & Trophis racemosa (L.) Urb. & 0 & 1 & 1 & 0 & 0 & 0 \\
\hline sp. 79 & Moraceae & Brosimum alicastrum Sw. & 1 & 1 & 1 & 1 & 1 & 0 \\
\hline sp. 80 & Meliaceae & Guarea sp. & 1 & 1 & 1 & 1 & 1 & 0 \\
\hline sp. 81 & Fabaceae & Inga sp. & 0 & 1 & 1 & 0 & 0 & 0 \\
\hline sp. 83 & Euphorbiaceae & Alchornea latifolia Sw. & 0 & 0 & 0 & 1 & 0 & 0 \\
\hline sp. 84 & Melastomataceae & Miconia impetiolaris (Sw.) D. Don ex DC. & 0 & 1 & 0 & 0 & 0 & 1 \\
\hline sp. 85 & Annonaceae & Cymbopetalum penduliflorum (Dunall) Baill. & 1 & 1 & 1 & 1 & 0 & 0 \\
\hline sp. 86 & & & 1 & 0 & 0 & 0 & 0 & 1 \\
\hline sp. 88 & Moraceae & Pseudolmedia sp. 1 & 1 & 1 & 1 & 1 & 0 & 0 \\
\hline sp. 90 & & & 0 & 0 & 0 & 0 & 1 & 0 \\
\hline sp. 91 & Arecaceae & Chamaedorea oblongata Mart. & 0 & 0 & 1 & 1 & 0 & 0 \\
\hline sp. 92 & & & 1 & 0 & 0 & 0 & 1 & 0 \\
\hline sp. 94 & Violaceae & & 1 & 0 & 0 & 0 & 0 & 0 \\
\hline sp. 95 & & & 0 & 1 & 0 & 0 & 0 & 1 \\
\hline sp. 96 & Commelinaceae & Tradescantia zanonia (L.) Sw. & 1 & 1 & 0 & 1 & 0 & 0 \\
\hline sp. 97 & & & 1 & 1 & 1 & 1 & 0 & 1 \\
\hline sp. 101 & Moraceae & Pseudolmedia sp. 2 & 0 & 0 & 0 & 1 & 0 & 0 \\
\hline sp. 102 & Arecaceae & Chamaedorea elegans Liebm. ex Mart. & 0 & 1 & 1 & 1 & 0 & 0 \\
\hline sp. 104 & & & 1 & 1 & 0 & 1 & 0 & 0 \\
\hline sp. 105 & Violaceae & Rinorea guatemalensis (S. Watson) Bartlett & 1 & 1 & 1 & 1 & 0 & 1 \\
\hline sp. 108 & & & 1 & 0 & 1 & 1 & 0 & 0 \\
\hline sp. 109 & Clusiaceae & Calophyllum brasiliense Cambess. & 1 & 1 & 0 & 0 & 0 & 1 \\
\hline sp. 110 & Malvaceae & Quararibea yunckerii Standl. & 1 & 1 & 0 & 1 & 0 & 0 \\
\hline sp. 113 & Anacardiacaee & Spondias mombin $\mathrm{L}$. & 0 & 1 & 0 & 1 & 1 & 0 \\
\hline sp. 116 & Sapindaceae & Cupania dentata Moc. \& Sessé ex DC. & 1 & 1 & 1 & 1 & 1 & 0 \\
\hline sp. 117 & Fabaceae & Bauhinia rubeleruziana Donn. Sm. & 0 & 1 & 0 & 1 & 0 & 1 \\
\hline sp. 118 & Rubiaceae & $\begin{array}{l}\text { Palicourea tetragona (Donn. Sm.) C.M. } \\
\text { Taylor \& Lorence }\end{array}$ & 1 & 1 & 1 & 0 & 1 & 1 \\
\hline sp. 119 & & & 0 & 0 & 0 & 1 & 0 & 0 \\
\hline sp. 120 & & & 0 & 0 & 1 & 0 & 0 & 0 \\
\hline sp. 121 & Sapotaceae & Pouteria dourlandii (Standl.) Baehni & 0 & 1 & 0 & 0 & 0 & 0 \\
\hline sp. 122 & Poaceae & & 0 & 0 & 0 & 0 & 1 & 0 \\
\hline
\end{tabular}


Appendix 2: Continuation.

\begin{tabular}{|c|c|c|c|c|c|c|c|c|}
\hline Id & Family & Species & Isma & bsma & Ismm & bsmm & laca & baca \\
\hline sp. 123 & & & 0 & 0 & 0 & 1 & 0 & 0 \\
\hline sp. 127 & & & 0 & 0 & 0 & 1 & 0 & 0 \\
\hline sp. 128 & Poaceae & & 0 & 1 & 0 & 1 & 1 & 1 \\
\hline sp. 129 & Violaceae & & 1 & 1 & 0 & 1 & 0 & 0 \\
\hline sp. 130 & Rubiaceae & & 0 & 1 & 0 & 0 & 0 & 0 \\
\hline sp. 131 & & & 0 & 1 & 0 & 1 & 0 & 0 \\
\hline sp. 132 & & & 0 & 1 & 0 & 1 & 0 & 0 \\
\hline sp. 141 & Arecaceae & Sabal sp. 1 & 1 & 1 & 0 & 1 & 0 & 0 \\
\hline sp. 143 & Fabaceae & Desmodium sp. & 0 & 0 & 0 & 0 & 1 & 0 \\
\hline sp. 146 & Fabaceae & Erythrina sp. & 0 & 1 & 0 & 0 & 0 & 0 \\
\hline sp. 147 & & & 0 & 1 & 0 & 1 & 1 & 0 \\
\hline sp. 149 & & & 0 & 0 & 0 & 0 & 1 & 0 \\
\hline sp. 151 & Sapotaceae & Pouteria sp. & 0 & 0 & 0 & 1 & 0 & 0 \\
\hline sp. 152 & Meliaceae & Guarea glabra Vahl & 0 & 0 & 0 & 0 & 1 & 0 \\
\hline sp. 153 & Piperaceae & Piper aeroginosibaccum Trel. & 0 & 0 & 1 & 0 & 1 & 0 \\
\hline sp. 154 & Rubiaceae & Rudgea cornifolia (Kunth) Standl. & 0 & 1 & 0 & 1 & 0 & 0 \\
\hline sp. 156 & Rubiaceae & Psychotria marginata Sw. & 0 & 1 & 0 & 1 & 0 & 0 \\
\hline sp. 157 & Rubiaceae & & 0 & 1 & 0 & 1 & 0 & 0 \\
\hline sp. 159 & & & 0 & 1 & 0 & 0 & 0 & 0 \\
\hline sp. 161 & Fabaceae & Dialium guianense (Aubl.) Sandwith & 0 & 1 & 0 & 1 & 0 & 0 \\
\hline sp. 163 & & & 0 & 1 & 1 & 0 & 0 & 0 \\
\hline sp. 164 & Moraceae & Cecropia peltata L. & 0 & 0 & 0 & 1 & 0 & 0 \\
\hline sp. 168 & Arecaceae & Sabal sp. 2 & 0 & 0 & 0 & 1 & 0 & 0 \\
\hline sp. 172 & Pteridaceae & Adiantum pulverulentum L. & 0 & 1 & 0 & 0 & 0 & 0 \\
\hline sp. 173 & Costaceae & Costus sp. & 0 & 1 & 1 & 1 & 1 & 1 \\
\hline sp. 174 & & & 1 & 1 & 1 & 0 & 0 & 0 \\
\hline sp. 175 & Rubiaceae & Psychotria pleuropoda Donn. Sm. & 0 & 0 & 0 & 1 & 0 & 0 \\
\hline sp. 178 & Poaceae & Olyra latifolia L. & 0 & 0 & 0 & 1 & 0 & 0 \\
\hline sp. 179 & & & 0 & 1 & 0 & 1 & 1 & 1 \\
\hline sp. 180 & & & 0 & 1 & 0 & 1 & 0 & 0 \\
\hline sp. 181 & Malpighiaceae & Bunchosia lindeniana A. Juss. & 0 & 0 & 1 & 0 & 0 & 0 \\
\hline sp. 183 & Ochnaceae & Ouratea luscens (Kunth) Engl. & 0 & 0 & 0 & 0 & 1 & 1 \\
\hline sp. 185 & & & 0 & 1 & 0 & 1 & 0 & 0 \\
\hline sp. 187 & Myrsinaceae & Ardisia nigrescens Oerst. & 0 & 0 & 0 & 1 & 0 & 1 \\
\hline sp. 188 & Musaceae & & 0 & 0 & 0 & 0 & 1 & 1 \\
\hline sp. 192 & & & 1 & 0 & 1 & 0 & 0 & 0 \\
\hline sp. 194 & & & 0 & 1 & 0 & 1 & 0 & 1 \\
\hline sp. 195 & Rubiaceae & Psychotria sp. & 0 & 0 & 1 & 0 & 1 & 0 \\
\hline sp. 197 & & & 0 & 0 & 0 & 0 & 1 & 1 \\
\hline sp. 198 & Rubiaceae & & 1 & 0 & 1 & 0 & 1 & 1 \\
\hline sp. 199 & & & 0 & 0 & 0 & 1 & 1 & 1 \\
\hline sp. 202 & & & 0 & 0 & 0 & 0 & 1 & 1 \\
\hline sp. 204 & & & 1 & 1 & 1 & 0 & 0 & 0 \\
\hline
\end{tabular}


Appendix 2: Continuation.

\begin{tabular}{|c|c|c|c|c|c|c|c|c|}
\hline Id & Family & Species & Isma & bsma & Ismm & bsmm & laca & baca \\
\hline sp. 206 & Rubiaceae & Psychotria pubescens Sw. & 0 & 0 & 0 & 0 & 1 & 1 \\
\hline sp. 207 & Fabaceae & & 0 & 0 & 1 & 0 & 0 & 0 \\
\hline sp. 208 & & & 1 & 0 & 0 & 0 & 0 & 0 \\
\hline sp. 209 & & & 0 & 1 & 0 & 0 & 0 & 0 \\
\hline sp. 213 & & & 0 & 0 & 1 & 0 & 0 & 0 \\
\hline sp. 215 & & & 0 & 1 & 0 & 1 & 0 & 0 \\
\hline sp. 216 & Flacourtiaceae & Casearia nitida Jacq. & 0 & 0 & 1 & 1 & 0 & 0 \\
\hline sp. 218 & Piperaceae & Piper aduncum L. & 0 & 0 & 0 & 0 & 0 & 1 \\
\hline sp. 223 & & & 1 & 0 & 1 & 0 & 0 & 0 \\
\hline sp. 229 & Commelinaceae & & 0 & 0 & 0 & 0 & 0 & 1 \\
\hline sp. 230 & Fabaceae & & 0 & 0 & 0 & 0 & 1 & 0 \\
\hline sp. 231 & Asteraceae & $\begin{array}{l}\text { Pseudelephantopus spicatus (Juss. ex Aubl.) } \\
\text { C.F. Baker }\end{array}$ & 0 & 0 & 0 & 0 & 1 & 1 \\
\hline sp. 232 & & & 0 & 0 & 0 & 1 & 0 & 0 \\
\hline sp. 233 & Poaceae & & 0 & 0 & 0 & 0 & 1 & 1 \\
\hline sp. 236 & & & 0 & 0 & 1 & 1 & 0 & 0 \\
\hline sp. 237 & Myrsinaceae & Ardisia nigropunctata Oerst. & 0 & 0 & 0 & 1 & 0 & 0 \\
\hline sp. 240 & Moraceae & & 0 & 0 & 0 & 0 & 1 & 0 \\
\hline sp. 243 & & & 0 & 0 & 0 & 0 & 1 & 0 \\
\hline sp. 246 & Rutaceae & Citrus $\times$ limon (L.) Osbeck & 0 & 0 & 0 & 0 & 1 & 0 \\
\hline sp. 247 & Amaranthaceae & Iresine sp. & 0 & 0 & 0 & 0 & 1 & 1 \\
\hline sp. 249 & Asteraceae & Hebeclinium macrophyllum (L.) DC. & 0 & 0 & 0 & 1 & 1 & 1 \\
\hline sp. 250 & Poaceae & & 0 & 1 & 0 & 0 & 0 & 1 \\
\hline sp. 252 & Verbenaceae & Lantana hispida L. & 0 & 0 & 0 & 0 & 0 & 1 \\
\hline sp. 253 & Asteraceae & Neurolaena lobata (L.) Cass. & 0 & 0 & 0 & 0 & 1 & 1 \\
\hline sp. 255 & Asteraceae & Baccharis trinervia (Lam.) Pers. & 0 & 0 & 0 & 0 & 1 & 0 \\
\hline sp. 256 & Piperaceae & Piper auritum L. & 0 & 0 & 0 & 0 & 0 & 1 \\
\hline sp. 257 & Fabaceae & Lonchocarpus sp. & 0 & 0 & 0 & 0 & 1 & 0 \\
\hline sp. 259 & Burseraceae & Bursera simaruba (L.) Sarg. & 0 & 0 & 0 & 0 & 1 & 0 \\
\hline sp. 262 & Denstaedtiaceae & Pteridium aquilinum (L.) Kunth & 0 & 0 & 0 & 0 & 1 & 0 \\
\hline sp. 263 & Asteraceae & Clibadium arboretum Donn. Sm. & 0 & 0 & 0 & 0 & 1 & 1 \\
\hline sp. 268 & Cyperaceae & Scleria gaertneri Raddi & 0 & 0 & 0 & 0 & 0 & 1 \\
\hline sp. 271 & Caricaceae & Vasconcellea cauliflora (Jacq.) A. DC. & 0 & 0 & 0 & 0 & 1 & 0 \\
\hline sp. 273 & Solanaceae & Lycianthes synanthera (Sendt.) Bitter & 0 & 0 & 0 & 0 & 0 & 1 \\
\hline sp. 275 & Rubiaceae & Hoffmannia riparia Standl. & 0 & 0 & 0 & 0 & 1 & 0 \\
\hline sp. 280 & & & 0 & 0 & 0 & 0 & 1 & 0 \\
\hline sp. 283 & Moraceae & & 1 & 0 & 1 & 0 & 0 & 0 \\
\hline sp. 285 & & & 1 & 1 & 0 & 0 & 0 & 0 \\
\hline sp. 286 & & & 1 & 0 & 0 & 0 & 0 & 0 \\
\hline sp. 287 & & & 0 & 0 & 0 & 0 & 1 & 0 \\
\hline sp. 288 & Rubiaceae & & 0 & 0 & 0 & 0 & 0 & 1 \\
\hline sp. 289 & & & 0 & 0 & 0 & 0 & 1 & 0 \\
\hline sp. 290 & & & 0 & 0 & 0 & 0 & 1 & 0 \\
\hline sp. 291 & & & 0 & 0 & 0 & 0 & 1 & 1 \\
\hline
\end{tabular}


Appendix 2: Continuation.

\begin{tabular}{|c|c|c|c|c|c|c|c|c|}
\hline Id & Family & Species & Isma & bsma & Ismm & bsmm & laca & baca \\
\hline sp. 293 & Araceae & & 0 & 0 & 0 & 0 & 0 & 1 \\
\hline sp. 294 & & & 1 & 0 & 1 & 0 & 0 & 0 \\
\hline sp. 295 & & & 0 & 0 & 1 & 0 & 0 & 0 \\
\hline sp. 296 & Polypodiaceae & & 0 & 0 & 1 & 0 & 0 & 0 \\
\hline sp. 297 & & & 1 & 0 & 0 & 0 & 0 & 1 \\
\hline sp. 298 & & & 1 & 0 & 1 & 0 & 0 & 0 \\
\hline sp. 299 & Polypodiaceae & & 1 & 0 & 0 & 0 & 0 & 0 \\
\hline sp. 300 & Polypodiaceae & & 0 & 0 & 0 & 1 & 0 & 0 \\
\hline sp. 301 & Euphorbiaceae & Acalypha diversifolia Jacq. & 0 & 0 & 0 & 1 & 1 & 1 \\
\hline sp. 303 & & & 0 & 0 & 0 & 0 & 0 & 1 \\
\hline sp. 304 & Cyperaceae & $\begin{array}{l}\text { Rynchospora radicans (Schltdl. \& Cham.) H. } \\
\text { Pfeiff. }\end{array}$ & 0 & 0 & 0 & 0 & 0 & 1 \\
\hline sp. 305 & & & 0 & 0 & 0 & 1 & 0 & 1 \\
\hline sp. 306 & & & 1 & 0 & 0 & 0 & 0 & 1 \\
\hline sp. 307 & Rubiaceae & Borreria laevis M. Martens \& Galeotti & 0 & 0 & 0 & 0 & 0 & 1 \\
\hline sp. 308 & Fabaceae & Mimosa ervendbergii A. Gray & 0 & 0 & 0 & 0 & 0 & 1 \\
\hline sp. 310 & & & 0 & 0 & 0 & 0 & 0 & 1 \\
\hline sp. 314 & Commelinaceae & & 0 & 1 & 0 & 1 & 0 & 1 \\
\hline sp. 315 & & & 0 & 1 & 0 & 0 & 0 & 1 \\
\hline sp. 317 & & & 0 & 1 & 0 & 1 & 0 & 0 \\
\hline sp. 319 & & & 0 & 0 & 0 & 0 & 0 & 1 \\
\hline sp. 320 & & & 0 & 0 & 0 & 0 & 0 & 1 \\
\hline sp. 321 & & & 0 & 0 & 0 & 0 & 0 & 1 \\
\hline sp. 323 & & & 0 & 1 & 0 & 1 & 1 & 0 \\
\hline sp. 329 & Poaceae & Streptochaeta spicata Schrad. ex Nees & 0 & 1 & 0 & 1 & 0 & 0 \\
\hline sp. 331 & & & 0 & 0 & 0 & 1 & 0 & 0 \\
\hline sp. 332 & & & 0 & 1 & 0 & 0 & 0 & 0 \\
\hline sp. 333 & Rubiaceae & Psychotria sp. & 0 & 1 & 0 & 0 & 0 & 0 \\
\hline sp. 335 & Orchidaceae & & 0 & 1 & 0 & 0 & 0 & 0 \\
\hline sp. 339 & Moraceae & Ficus sp. & 0 & 1 & 0 & 0 & 0 & 0 \\
\hline sp. 340 & Iridaceae & Neomarica gracilis (Herb.) Sprague & 0 & 1 & 0 & 0 & 0 & 0 \\
\hline sp. 341 & & & 0 & 1 & 0 & 0 & 0 & 0 \\
\hline sp. 342 & & & 0 & 1 & 0 & 0 & 0 & 0 \\
\hline sp. 343 & & & 0 & 1 & 0 & 0 & 0 & 0 \\
\hline sp. 345 & & & 0 & 1 & 0 & 0 & 0 & 0 \\
\hline sp. 346 & Passifloraceae & Passiflora sp. & 0 & 0 & 0 & 0 & 0 & 1 \\
\hline sp. 347 & & & 0 & 0 & 0 & 0 & 1 & 0 \\
\hline sp. 349 & Araceae & & 0 & 0 & 1 & 0 & 1 & 0 \\
\hline sp. 350 & & & 0 & 1 & 0 & 1 & 1 & 1 \\
\hline sp351 & & & 1 & 0 & 0 & 0 & 1 & 0 \\
\hline sp. 352 & & & 0 & 0 & 0 & 0 & 1 & 1 \\
\hline sp. 353 & & & 1 & 0 & 0 & 0 & 1 & 0 \\
\hline sp. 355 & & & 0 & 0 & 1 & 0 & 0 & 0 \\
\hline sp. 356 & & & 1 & 0 & 0 & 0 & 0 & 0 \\
\hline
\end{tabular}


Appendix 2: Continuation.

\begin{tabular}{|c|c|c|c|c|c|c|c|c|}
\hline Id & Family & Species & Isma & bsma & Ismm & bsmm & laca & baca \\
\hline sp. 357 & & & 1 & 0 & 0 & 0 & 0 & 0 \\
\hline sp. 358 & & & 1 & 0 & 0 & 1 & 0 & 0 \\
\hline sp. 359 & & & 0 & 0 & 0 & 1 & 0 & 0 \\
\hline sp. 360 & & & 0 & 0 & 0 & 1 & 0 & 0 \\
\hline sp. 361 & & & 0 & 0 & 0 & 1 & 0 & 0 \\
\hline sp. 364 & & & 0 & 0 & 0 & 1 & 0 & 0 \\
\hline sp. 365 & Rubiaceae & & 0 & 0 & 0 & 1 & 0 & 0 \\
\hline sp. 366 & & & 0 & 0 & 0 & 1 & 0 & 0 \\
\hline sp. 367 & Araceae & & 0 & 0 & 0 & 1 & 0 & 0 \\
\hline sp. 368 & & & 0 & 1 & 0 & 1 & 0 & 0 \\
\hline sp. 369 & Rubiaceae & & 0 & 1 & 0 & 0 & 0 & 0 \\
\hline sp. 372 & Urticaceae & Urera sp. & 0 & 0 & 0 & 0 & 0 & 1 \\
\hline sp. 377 & & & 0 & 0 & 0 & 0 & 0 & 1 \\
\hline sp. 392 & & & 1 & 0 & 0 & 0 & 0 & 0 \\
\hline sp. 394 & & & 0 & 0 & 0 & 0 & 0 & 1 \\
\hline sp. 398 & Asteraceae & & 0 & 0 & 0 & 1 & 0 & 0 \\
\hline Total & & & 69 & 96 & 74 & 96 & 67 & 59 \\
\hline
\end{tabular}

